\title{
Recent changes in plant and animal distribution in the southern extreme of the Paranaense biogeographical province (northeastern Buenos Aires province, Argentina): Ecological responses to climate change?
}

\author{
Elián Leandro GUERRERO ${ }^{1}$ \& Federico Lisandro AGNOLIN ${ }^{2,3}$
}

\begin{abstract}
${ }^{1}$ División Plantas Vasculares Dr. Ángel L. Cabrera, Herbario LP. Museo de La Plata. La Plata, Argentina. eguerrero@fcnym.unlp.edu.ar; ${ }^{2}$ Laboratorio de Anatomía Comparada y Evolución de los Vertebrados, Museo Argentino de Ciencias Naturales "Bernardino Rivadavia". Buenos Aires, Argentina; ${ }^{3}$ Departamento de Ciencias Naturales y Antropología, Fundación de Historia Natural "Félix de Azara”, Universidad Maimónides. Buenos Aires, Argentina.
\end{abstract}

\begin{abstract}
The Northern region of Buenos Aires province, in Argentina, suffered an uninterrupted increase in rainfall and temperature values during the last decades. The aim of the present contribution is to analyze the effects of such climatic change in the distribution of local flora and fauna. The analysis resulted in the recognition of distributional shifts in a total of 115 species. These changes represented the progressive southern expansion of species typically present in subtropical areas. Because all these changes have a similar orientation and direction, and included a large number of plant and animals with different ecological requirements, it is here postulated that those geographical changes are probably a response to climatic alteration.
\end{abstract}

Key words: Buenos Aires; climate change; riparian forest; species distribution.

Resumen: Cambios recientes en la distribución geográfica de plantas y animales en el extremo sur de la provincia biogeográfica Paranaense (noreste de la provincia de Buenos Aires, Argentina): ¿Respuestas ecológicas al cambio climático? La región norte de la provincia de Buenos Aires, en la Argentina, sufrió un incremento ininterrumpido de los valores de precipitación y temperatura durante las últimas décadas. El objetivo de esta contribución es analizar los efectos de dicho cambio climático en la distribución de la flora y fauna locales. El análisis resultó en el reconocimiento de corrimientos en la distribución de un total de 115 especies. Estos cambios representaron una expansión progresiva hacia el sur de especies presentes típicamente en áreas subtropicales. Como todos estos cambios tienen una orientación y dirección similares, e incluyen un gran número de plantas y animales con diferentes requerimientos ecológicos, se postula que estos cambios de distribución geográfica son probablemente una respuesta a la alteración climática.

Palabras clave: Buenos Aires; cambio climático; bosques en galería; distribución de especies.

\section{INTRODUCTION}

Buenos Aires province is located in EastCentral Argentina. It is biogeographically integrated within the Pampean biogeographical province, of the Chacoan dominion in the Chacoan sub-region (Cabrera, 1971; Morrone, 2014; Figure 1). Most of Buenos Aires province is characterized by grasslands (locally named "pampas") and Celtis ehrenbergiana xerophytic woods (locally named "talares") both typical of the Pampas biogeographical province (Morrone, 2014). However, subtropical gallery rainforests and coastal forests from northeastern Argentina have their southernmost limit of distribution alongside large rivers to the La Plata River latitude (Cabrera, 1971; Figure 2). From an Ecoregional framework, Burkart et al (1999) named this complex "Delta and Paraná Islands Ecoregion". Riparian rainforest's plants belong to the Paranaense biogeographical province (Cabrera \& Dawson, 1944; Cabrera, 1971) whereas coastal-forest plants and animals are widespread in Chaco and Paranaense provinces (Ringuelet, 1955). Then, in northeastern Buenos Aires province, Paranaense flora and Subtropical fauna intergrades with Pampean biota, forming an ecotone (the "subtropical-pampásico" ecotone sensu Ringuelet, 1961, 1981).

Climatic change is largely known to affect 


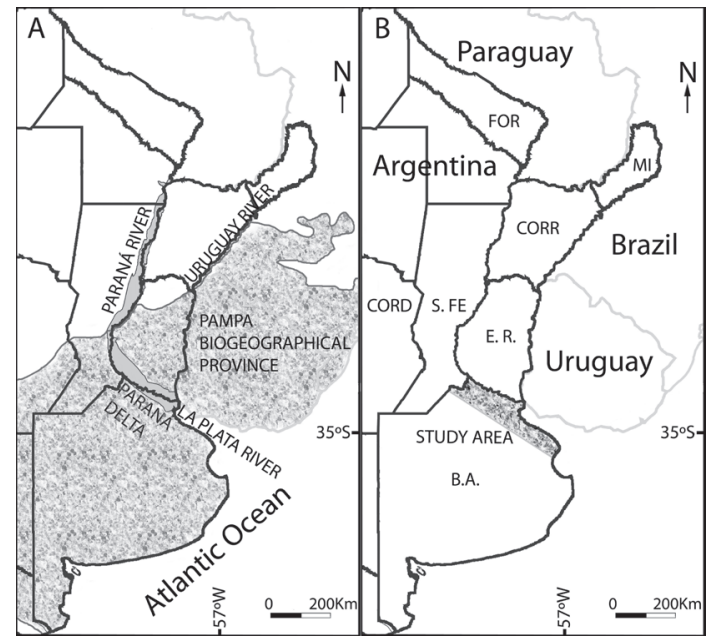

Fig. 1: Map of northeastern Argentina and bordering countries. A: Biogeographical units. In grey = Paraná River floodplain (Delta and Paraná Islands ecorregion of Burkart et al., 1999); Dotted = Pampa Biogeographical province sensu Morrone (2014). B: Political division. Argentinean provinces mentioned in the main-text: $\mathrm{MI}=$ Misiones; FOR = Formosa; CORR = Corrientes; $\mathrm{S} . \mathrm{FE}=$ Santa Fe; CORD = Córdoba; E.R. = Entre Ríos; B.A. = Buenos Aires.

plant and animal distribution, having diverse effects on biotic communities and ecosystems (McCarty, 2001; Walther et al., 2002; Parmesan, 2006; Walther, 2010). Climatological studies in Argentina show that during the $20^{\text {th }}$ century, Buenos Aires province suffered an uninterrupted increase in precipitation and temperature values (Berbery et al., 2006; Menéndez, 2006; Servicio Meteorológico Nacional, 2015; Barros et al., 2015). Having in mind such large-scale climatic change, a poleward shift in the geographical distribution of plant and animal communities is expected.

In spite of that, an integrative study about the impacts of recent climate change on Argentinean ecosystems is still lacking. Studies about changes in species geographical distribution related to climatic variation were mainly conducted in mammals (e.g. Udrizar Sauthier et al., 2005; Fracassi et al., 2010), medically important snakes (Nori et al., 2013), insects (Farina, 2006; Medone et al., 2015), and arachnids (Guerrero, 2014a). Furthermore, there is a single phenological study of changes in arriving times of a migratory swallow (Spescha et al., 2004). Nevertheless, each one of these works focus on single species or on a small taxonomic group of animals. On the other hand, plant species range shifts deserved almost no attention. The aim of this paper is twofold:

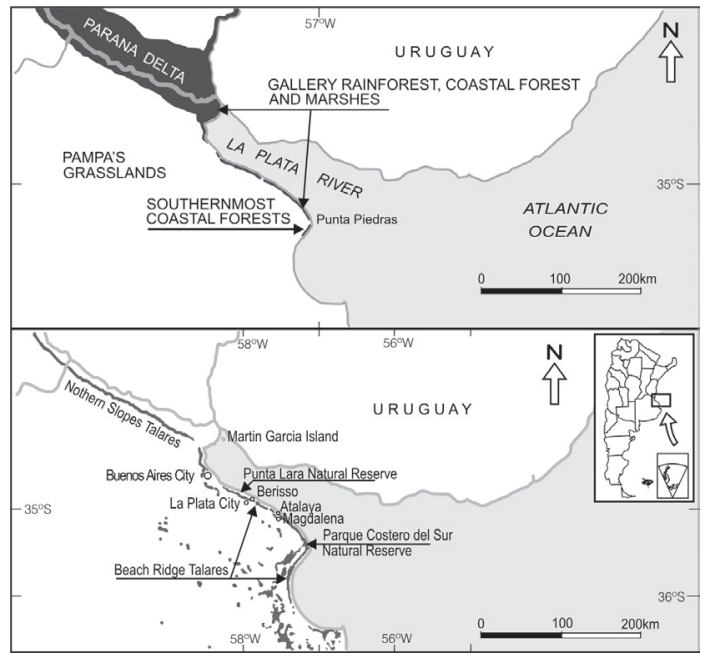

Fig. 2: Physical features of the study area and sites mentioned in the text.

first, to show that geographical changes in species are not isolated and that there is a common tendency to extend the southern limit of subtropical plant and animal species; and second: to examine if the observed shifts on animal and plant species distribution could be attributed to climatic change.

\section{MATERIALS AND METHODS}

\section{Geographical settings}

We analyzed the northeastern sector of Buenos Aires province, where Paranaense riparian forests have their southernmost patches along the coast of the Lower Paraná and La Plata rivers (Figure 2). We restricted our research to this area because it was largely considered as the best known region in Argentina from a biological viewpoint, and because it was the focus of study of several researchers during the $19^{\text {th }}$ and $20^{\text {th }}$ centuries. Consequently, large biological collections are available from this area since historical times. This allows comparison between old and recent collections. We did not include central and southern Buenos Aires province, even though some recent cases of shifts on animal species distributions were probably caused by climate change (e.g. Zamorano \& Scillato-Yané, 2008; Doumecq-Milieu et al., 2012). This is because those areas were poorly sampled by researchers in historical times.

From north to southeast, Pergamino, San Nicolás, Ramallo, San Pedro, Baradero, Zárate, Campana, Pilar, Zelaya, Tigre and San Isidro districts, together with Martín García Island 
encompasse the northern boundary of Buenos Aires province, including Paraná's Delta and slope talares; from Buenos Aires City to the southeast are located the districts of Avellaneda, Quilmes, Berazategui, Ensenada, La Plata, Berisso, Magdalena and Punta Indio; Punta Lara Natural Reserve is placed between Berazategui and Ensenada districts, and Parque Costero del Sur Natural Reserve in Magdalena and Punta Indio districts.

\section{Taxon selection}

Analyzed taxa were chosen under two main criteria. Firstly, we selected relatively well-studied species from the biogeographical point of view. On the other hand, we analyzed if a comparison between old and recent researches was possible. Consequently, we analyzed selected vascular plants, harvestmen (Arachnida, Opiliones), spiders (Arachnida, Araneae), Rhopalocera butterflies (Insecta, Lepidoptera), and some vertebrates, including birds (Aves), chelonians (Testudines), and mammals (Mammalia). Present paper is based on an exhaustive review of published literature and our own research. Distributional areas in each case were determined from bibliographical data such as catalogues and reviews. Below is a brief review of the bibliography and collections we examined for each group:

Vascular plant distribution. The oldest wellreferenced collections from La Plata River coast are those of John Tweedie (between 1825 and 1832) and Carlos L. Spegazzini (in 1880 decade). Nikolai M. Alboff, Carlos Berg, Lucien Hauman, Cristóbal Hicken, and many others collected a big amount of specimens in the area by the late $19^{\text {th }}$ and early $20^{\text {th }}$ centuries. Collections and works on the provincial flora increased quickly, and the monumental work "Flora de la provincia de Buenos Aires", directed by Ángel L. Cabrera (1963-1970) summarized the knowledge of plant species distribution in this province up to that date. Therefore this document became the basis for any further study, including the present contribution. Additional data was achieved from specialized works, especially about ferns (e.g. Capurro, 1961).

Arachnida distribution. We included in this item the clades Opiliones and Araneae. Opiliones in Argentina were studied in great detail by Raúl A. Ringuelet. Analyses of Ringuelet's monograph about Argentinean species of the clade (1959) shows that northeastern Buenos Aires province is the area with most previous collection sites, probably due to its proximity to Buenos Aires and La Plata natural science mu- seums (Acosta, 2014). Therefore, we infer that knowledge of haverstmen in this area is relatively good. Furthermore, in this part of the province several harvestmen that distribute along the Argentinean Mesopotamia (the geographical area encompassed between Paraná and Uruguay rivers) have their southern limit of geographical distribution (Ringuelet, 1959; Acosta, 2002). On the contrary, because the Araneae are not well studied on a zoogeographical point of view, only a brief analysis of two well-studied genera is added.

Lepidoptera distribution. Lepidoptera species were shown to be very useful in climatic change studies, with many responses to that phenomenon (Kocsis \& Hufnagel, 2011). During the last decade, butterfly communities in northeastern Buenos Aires province were analyzed in detail in some sparse localities (Núñez Bustos, 2007, 2008, 2009; Núñez Bustos et al., 2013). However, well-sampled old lepidopteran collections were made by researchers by late $19^{\text {th }}$ and early $20^{\text {th }}$ centuries (Breyer, 1939b; Hayward, 1973; Canals, 2000). In this way, it is possible to made useful comparisons between old collections and recent observations. When Hayward's comprehensive catalogue (1973) is compared with recent works (Canals, 2000; Núñez Bustos, 2007; 2008; 2009; Núñez Bustos et al., 2013), a significant number of species were added recently to Buenos Aires fauna.

Bird distribution. The avifauna of Buenos Aires city and neighboring region was studied by the late $19^{\text {th }}$ century by several authors (d'Orbigny, 1847; Burmeister, 1868; Lynch Arribálzaga, 1878; Holmberg, 1878, 1898; Sclater \& Hudson, 1888; Narosky \& Gallegos, 1992), and since then, this coastal zone has been considered as the best known area of Argentina from the ornithological point of view. Later works, like those of Olrog $(1963,1979)$ and Narosky \& Di Giacomo (1993) allow good comparisons and recognition of main distributional patterns.

Chelonia distribution. Knowledge of the distribution of reptiles and amphibians in the northeastern sector of Buenos Aires province is still patchy and biased. Among them, it is possible that the best known group are the turtles, probably because they are easy to observe and identify. Furthermore, as indicated by Crick \& Sparks (1999), the turtles are very sensitive and climate-affected taxa, mainly because their nestling is climate-driven. Information on geographic distribution of chelonians was taken from the exhaustive papers by Freiberg (1977), Gallardo (1977), and Cabrera (1998). 


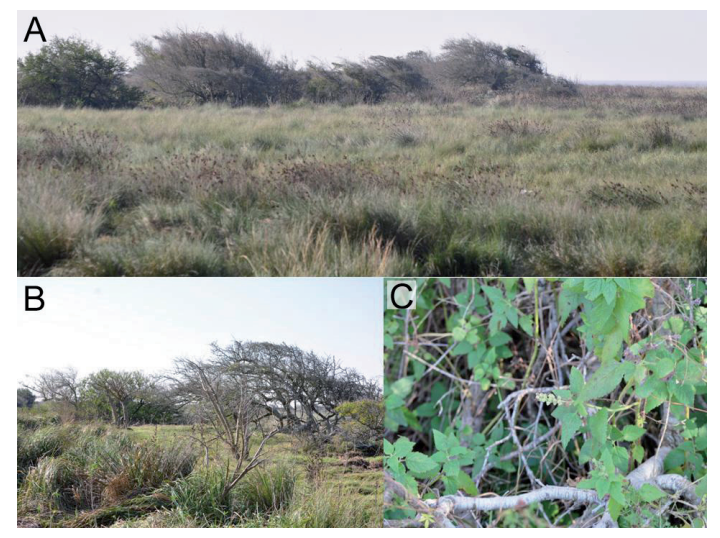

Fig. 3: Southernmost Erythrina crista-galli L. forests in Samborombón Bay. A-B: General view of the trees along the river coast (winter condition). C: Teucrium vesicarium Mill., a typical herb of the La Plata River hygrophilous forests.

Mammalia distribution. Small mammals, especially rodent, have been found as valuable sources indicative of climate regime (Cameron \& Scheel, 2001). In Argentina, most studies regarding detailed distribution and taxonomy of smallmammals were carried out by the relatively recent efforts of Elio Massoia by the 1960 decade. An important contribution is that of Galliari et al. (1991), which stands as the main compilation of mammalian records of the province up to that date. Since then, the studies on micromammal assemblages in Buenos Aires have been greatly increased (e.g., Udrizar Sauthier et al., 2005; Teta et al., 2010, 2014; Pardiñas et al., 2010), but unfortunately species distribution in Buenos Aires province is still far from being well-understood. Therefore, we focus our work on middle mammals, which are well represented in public collections, they are usually well known by hunters, and are mentioned in $19^{\text {th }}$ century explorers' books.

\section{RESULTS}

\section{Changes in vascular plants distribution}

A total of 44 distribution changes in vascular plant species was confirmed (Table 1).

Many novel species records are here made for the first time in the Punta Lara gallery rainforest. First explorations to this Natural Reserve were made by Nicolás M. Alboff, Carlos L. Spegazzini and Lucien Hauman by the late $19^{\text {th }}$ and early $20^{\text {th }}$ centuries. Later, Ángel L. Cabrera and collaborators studied extensively this rainforest between 1926 and 1944 (Cabrera \& Dawson, 1944). Plant collections in that place did not stop after that, and late to Cabrera \& Dawson's work, new information was available during the preparation of the "Flora de la provincial de Buenos Aires" (Cabrera, 1963-1970). More recently, the exhaustive efforts of Flavio Moschione (1987, 1992) and Moschione \& Klimaitis (1988) resulted in the addition of 17 new records of native plant species to Punta Lara's flora. Finally, Giudice et al. (2011) collected other three fern species not previously found in that locality. The works commented here were conducted in the same 6.6 hectares of the Punta Lara Natural Reserve. It is surprising that after 100 years of botanical research in this relatively small area, the increase in species richness did not reach the asymptote.

The progressive enrichment of the flora in this region, as noted by the above mentioned authors, is due to the conquest of plants from more northern locations. The "bugre", Lonchocarpus nitidus, is a particular case. In Buenos Aires province it grows in the lower Paraná Delta, Martín García Island, Avellaneda and Quilmes districts, and has its southernmost populations in the Punta Lara Natural Reserve. This legume tree is one of the most important components of Punta Lara riparian rainforest (e.g. Cabrera \& Dawson, 1944; Dascanio \& Ricci, 1988) and Martín García Island forest (Arturi \& Juárez, 1997). However, it is curious that there are no collected specimen from there or any another part of the province up to 1925 (Paraná Delta, 1925, collected by A. C. Scala, deposited in LP herbarium). Because the species grows in an area that was visited several times by botanists during the end of the $19^{\text {th }}$ and early $20^{\text {th }}$ centuries, it is unlikely that this big ornamental plant was overlooked in the Punta Lara forest. Its distributional shift may have occurred at the end of $19^{\text {th }}$ century, and represents an example of early distributional expansion.

\section{Changes in plant communities distribution}

Leaving aside individual species range extensions, an expansion of the entire Paranaense coastal woods is documented. When comparing the southern limit of this plant community as observed by Vervoorst (1967) with today limit, we realize this wood advanced more than 25 kilometers to the south, from Salvador Grande Point to the northern limit of Samborombón Bay (both sites in Parque Costero del Sur Natural Reserve, Punta Indio district). In this regard, lineal patches of a coastal forests are present in a beach ridge between $35^{\circ}$ 30,219' $\mathrm{S}-57^{\circ}$ 9,795' $\mathrm{W}$ and $35^{\circ} 30,447^{\prime} \mathrm{S}-5^{\circ}$ - $10,019^{\prime} \mathrm{W}$ (Figures 2 and 3). There, the characteristic tree Erythrina crista-galli is associated with Acacia caven, Sesbania punicea, S. virgata, Senna corymbo- 


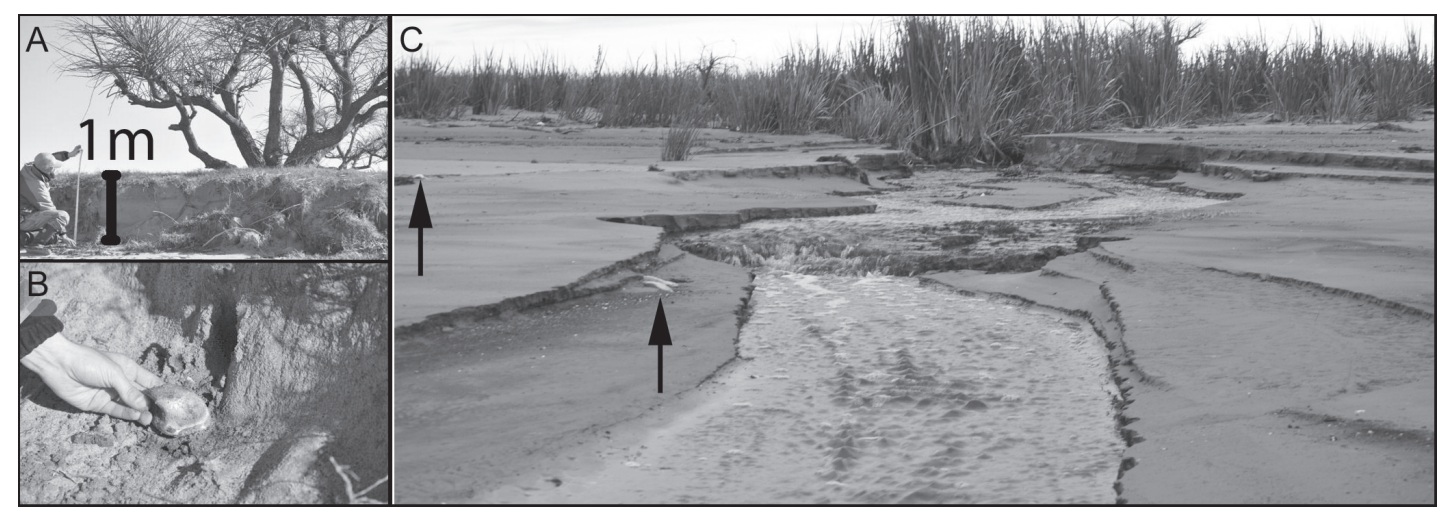

Fig. 4: Some sedimentary features of Punta Indio ridges (Parque Costero del Sur). Redrawn from Guerrero (2014a). A: General view of a stratigraphic cut in Erythrina crista-galli forests at Punta Indio. B: Detail of the same stratigraphic cut. Note the plastic buoy taken from the lower part of the strata. C: Recently formed ridge. Arrows indicate plastic waste embedded in the geoform.

sa, Celtis ehrenbergiana, Elymus scabrifolius, Cynodon dactylon, Hibiscus striatus, Hydrocotyle bonariensis, Teucrium vesicarium, Eclipta prostrata, Tillandsia aëranthos, Passiflora caerulea, Ipomoea cairica and Araujia sericifera. This association conforms a Paranaense woodland of very recent origin, showing that the forest is actually extending its distribution to southern latitudes.

It is also worth mentioning that several humid forests within the Parque Costero del Sur Natural Reserve may have appeared within the area during the $20^{\text {th }}$ century, as inferred from sedimentary evidence (Guerrero, 2014a). In fact, there is a fine sand stratum of about one meter thick carrying human solid waste under the soil where the forest grow up, and in some places a thin mud stratum with plastic fragments underlies the previous one (Figure 4). On this basis, it was concluded that the forests obviously grew up after these strata have settled down, and the presence of plastics within the sediment indicates they were deposited during the $20^{\text {th }}$ century (Guerrero, 2014a).

\section{Changes in Arachnida distribution}

Table 2 summarizes taxa with recent extensions on their geographical distributional area.

A total of 6 harvestmen (Opiliones) species have increased their distributional range from north to south along the La Plata River fluvial system: Discocyrtus prospicuus, Discocyrtus testudineus, Gryne orensis, Hernandaria scabricula, Metalibitia argentina and Varinodulia insularis. The southward expansion of Mesopotamian harvestmen species is strikingly coincident with the increase of rainfall and temperature in Buenos Aires province (Guerrero, 2014a). This distributional change was proposed as a climatedriven phenomenon that produced first geomorphological modifications, then physiognomic changes in the flora, and finaly harvestmen colonization (Guerrero, 2014a).

Among spiders, we recognize distributional changes in Nephila clavipes and Neotrops pombero. The first one is a good example of a recent southward expansion. This subtropical spider reached Corrientes province as its southern limit up to the 2000 s, but to present time occurs on almost every humid coastal wood from Paraná Delta to Punta Indio district (Guerrero et al., 2012). Dispersion of Nephila clavipes was related to a flood event that swept some spiders downstream to north Buenos Aires. Neotrops pombero is a common species in northeastern Argentina and Paraguay (Grismado \& Ramírez, 2013). Its sudden appearance in Costanera Sur Ecological Reserve in 2011 was attributed to a recent dispersal (Grismado \& Ramírez, 2013; Zapata \& Grismado, 2015). Many other spider species may have reached the study area in the last decades, but unfortunately lot of research is needed (Zapata \& Grismado, 2015). For example, Micrathena furva (Keyserling 1892) was recorded by Levi (1985) up to Punta Lara Natural Reserve, but nowadays it extends southwards to Parque Costero del Sur Natural Reserve (Arachnological collection of La Plata Museum, La Plata, Buenos Aires, Argentina: MLP_Ar 19407).

\section{Changes in lepidopteran distribution}

Southward expansions were detected in butterfly species from different localities at Buenos Aires province. 33 taxa were found as having important distributional changes (Table 3). 
Morpho epistropheus argentinus, considered the national butterfly due to its beauty, is a big and conspicuous species on its adult and larval stages. Farina (2006) followed the increase of its range extension across the eastern part of the province between 1985 and 2003. Up to 1939 the species was known from a few localities of northern Buenos Aires province, its southern limit being at Punta Lara (Breyer, 1939a). To early 2000s it expanded its range to Punta Piedras (Punta Indio district) and General Madariaga district (Klimaitis, 2000). Finally, a few years later it was detected in the southern General Pueyrredón district (Farina, 2006). As its favorite host plant, Scutia buxifolia (Rhamnaceae), exists in the xerophitic woods or "talares" almost since the beginnings of the $20^{\text {th }}$ century (Parodi, 1940), Farina (2006) concluded that the range expansion of this butterfly could be connected with the climatic change. Also, Hypanartia bella, Doxocopa laurentia laurentia, Phoebis neocypris, and $P$. sennae marcelina showed the same pattern of southward extension through the "talares" (Farina, 2006).

Another remarkable case is Adelpha syma, of which the original distribution encompasses southeastern Brazil, Uruguay, Paraguay and northeastern Argentina, was not reported in Buenos Aires province prior to the 2000s (Hayward, 1973; Willmott, 2003). Klimaitis (2000) argued the species arrived to the area due to passive raft dispersal downstream the Paraná or Uruguay rivers or by active dispersal along the Atlantic coast. Nowadays it is a common butterfly in several sites of northeastern Buenos Aires province (Núñez Bustos et al., 2013).

Finally, some species increased their abundance during the last decades. For example, Núñez Bustos et al. (2013) mention that Badecla argentinensis, which had scarce past records in Buenos Aires, became much more frequent in recent decades.

\section{Changes in chelonian distribution}

As a result of comparing old works with recent papers and observations, we found that three turtle species changed their geographical distribution and expanded its geonemy (Table 4).

The case of the Red eared slider Trachemys dorbignyi merits some explanatory comments. This species is frequent in northeastern Argentina, north to Entre Ríos province (Barco \& Larriera, 1991; Richard \& De La Fuente, 1992; Cabrera, 1998). Freiberg (1977; probably based on Marelli, 1924) mentioned its presence in Buenos Aires, but this report was not based on actual specimens and was considered as dubious (Richard \& De La Fuente, 1992; Cei, 1993; Alcalde et al., 2012). Consequently, Williams (1991) did not include the species within Buenos Aires herpetofauna, a criterion followed by many authors. In the last decade this turtle was found in several localities of northern Buenos Aires province: San Isidro and Campana districts, and Buenos Aires city (Pereira \& Haene, 2003; Chebez, 2009; Agnolin et al., 2014), possibly Punta Lara (Saibene et al., 2012), and in Magdalena, which constitutes its current southernmost locality (Alcalde et al., 2012). Thus, we consider these records corroborate the hypothesis of a geographical expansion in this species.

Hydromedusa tectifera was recently found in Sierra de La Ventana, 495 kilometers south of its previously known geographic distribution (Di Pietro et al., 2012). We did not include this record here because it is unclear if it is due to a recent natural expansion or human introduction. However, the new record here reported at Punta Indio district (Arroyo Salvador Grande, near the bridge of Route 11, 7 January 2009) may be an evidence of a natural southward expansion of the species following La Plata River coast.

\section{Changes in bird distribution}

Several authors considered that some bird species inhabiting the La Plata River coast expanded their southern distribution in recent times (Haene, 2006; Chimento et al., 2011; Godoy et al., 2012; Agnolin \& Rivero, 2014). Based on available data, at least 24 different species of birds can be considered as being more widely distributed than previously known (Table 5).

All the species included in the table were scarce or absent from Buenos Aires province but they are frequent nowadays and were reported from many localities. Among them, most taxa are related to woodland habitats, both aquatic (Anhinga anhinga, Tigrisoma lineatum, Aramides cajanea) and terrestrial (Penelope obscura, Columba picazuro, Columbina talpacoti, Tapera naevia, Crotophaga ani, Leucochloris albicollis, Picumnus cirratus, Melanerpes candidus, M. cactorum, Phacellodomus ruber, Thamnophilus caerulescens, Hemitriccus margaritaceiventer, Euscarthmus meloryphus, Basileuterus leucoblepharus, Saltatricula multicolor, Saltator aurantiirostris, Cyanocompsa brisonii), whereas a minor component includes taxa of more opened areas and generalist habits (Elaenia spectabilis, Phylloscartes ventralis, Sporophila hypochroma, Sporophila cinnamomea) (Nores et al., 2005). 
We include below a brief account of some remarkable species that, according to current records, habits, and visibility, are known to have expanded its geographical distribution southwards.

The Darter Anhinga anhinga inhabits freshwater environments surrounded by wooded areas of northeastern Argentina (Olrog, 1963; Narosky \& Di Giacomo, 1993). Narosky (1969) was the first author reporting its presence in Buenos Aires; its nestling was later corroborated by López Lanús \& Roda (1987). Since then, it was reported from several localities of the province and Buenos Aires city. Its southernmost record is from the Punta Lara Natural Reserve (Narosky \& Di Giacomo, 1993; Babarskas et al., 2003; Pugnali \& Chamorro, 2006; Pagano et al., 2012).

The Guan Penelope obscura is common in wood areas and forests from northeastern Argentina (Olrog, 1963; Narosky \& Di Giacomo, 1993). Césari \& Alonso (1975) cited the species for the first time in the northern tip of Buenos Aires province, and since then it was found in several localities, including the Paraná Delta (Narosky \& Di Giacomo, 1993), Otamendi (Babarskas et al., 2003), Punta Indio (F.L. Agnolin pers. obs.), Buenos Aires city (Eguía, 2012), and more recently, maped in Punta Rasa (Narosky \& Yzurieta, 2010).

The Woodpecker Melanerpes cactorum was first reported for the province in the locality of Ramallo (Maugeri \& Montenegro, 2002). Recently, Chimento et al. (2009) reported for the first time that this species nests in La Plata city, 250 kilometers to the south of its previously known distribution. More recently, the species was repeteadly reported for Buenos Aires and La Plata cities (Chimento et al., 2011; Borsellino, 2012), and Vuelta de Obligado, San Pedro district (Chimento et al., 2011). The presence and nestling of the species on its southern geographical limit was considered by Chimento et al. (2011) as probably driven by climatic changes in the region.

The Green-backed Becard Pachyramphus viridis was observed for the first time in Buenos Aires province in 1989 (Narosky \& Di Giacomo, 1993). Since then, the species expanded its distribution to severallocalities of thearea (Krapovickas et al., 1992; Narosky \& Di Giacomo, 1993; Grilli \& Areta, 2002; Bodrati, 2001; Bodrati et al., 2006; Areta in Pagano \& Mérida, 2009). Similarly, the Cardinal Paroaria capitata was not observed by ancient authors in the province (e.g., Holmberg, 1898; Burmeister, 1868; Pereyra, 1938). Klimaitis $\&$ Moschione (1987) stated the species was pres- ent though very scarce in Punta Lara. Narosky \& Di Giacomo (1993) reported a large amount of localities at northern and eastern Buenos Aires province, and Pugnali and Chamorro (2008) and Zelaya \& Pérez (2008) indicated that this species currently is common in Buenos Aires city. Also Chimento et al. (2012) reported new records for the Cardinal and said that it probably expanded its geographical range to the south of the province in recent times. Likewise, the Saltator Saltator similis was first found in the northern extreme of Buenos Aires province by Fernández (1991). Since then, it was found in other localities of the province, including Punta Lara and Atalaya (Bodrati et al., 2001b; Mérida \& Bodrati, 2006; Bodrati \& Sierra, 2009), and Buenos Aires city (Pugnali \& Chamorro, 2008).

Previous to the 1980s, Phacellodomus ruber presence in Buenos Aires province was inferred from a single skin coming from Avellaneda district (Narosky \&Di Giacomo, 1993). This species is related to wooded areas and forests from northern Argentina north to Santa Fe province (Olrog, 1963, 1979). However, since 1989 the species has become more frequent in different localities at northeastern Buenos Aires province (Chebez \& Haene, 1991; Narosky \& Di Giacomo, 1993; Bodrati et al., 2001a). Bodrati et al. (2001a) considerably expanded the knowledge of the species in the province, and indicated that it is relatively frequent in Vuelta de Obligado (San Pedro district), where it nests. Similarly, in the early $20^{\text {th }}$ century Thamnophilus caerulescens had only two records in northeastern Buenos Aires province (Sclater, 1890; Holmberg, 1898), and was considered a rare species in the province by Narosky \& Di Giacomo (1993). More recently, it was frequently reported in the studied area, with records from Zárate, San Isidro, Campana, San Pedro, Baradero and Llavallol districts, and Buenos Aires city (Narosky, 1983; Barbetti et al., 1985; Babarskas et al., 2003; Bodrati et al., 2001a; Pugnali \& Chamorro, 2008; Lucero et al., 2011). Furthermore, in Baradero and Llavallol districts the species is relatively frequent (Bodrati et al., 2001a).

Several other species that were considered rare, scarce or hypothetical for Buenos Aires have been increasing its occurrence in the region. For example, up to late 1980s the Woodcreeper Lepidocolaptes angustirostris was considered a very rare species at Punta Lara Natural Reserve (Klimaitis \& Moschione, 1987), whereas more recently it is considered "very common" and frequent in all environments (Pagano et al., 2012). The species is also very common in Buenos 
Aires city (F. L. Agnolin pers. obs.), and has expanded its southern and western distribution in several counties of the province (Haene, 2006; Chimento et al., 2012). The same may be said for Myiodynastes maculatus, which was a rare resident on the northern tip of the province, with only a few records (Narosky \& Di Giacomo, 1993). Recent overviews indicate that the species is common at several localities, including La Plata city (F. L. Agnolin pers. obs.), Llavallol (Lucero et al., 2011), Avellaneda and Quilmes districts (Godoy et al., 2012), and Punta Lara Natural Reserve (Pagano et al., 2012). A similar pattern may be recognized for the Trushes Turdus rufiventris and T. amaurochalinus. The fomer was considered scarce by d'Orbigny (1847) and Withington (1888) in Buenos Aires neighborhood. However, since the 1960s the species has been increasing its abundance in the province (Narosky, 2012). Nowadays, this Thrush is probably one of the most frequent birds in several localities, including Buenos Aires city (Narosky, 2012; Narosky et al., 1996; Haene, 2006) and expanded its distribution towards the south in Buenos Aires province. Similarly, T. amaurochalinus was an uncommon species in the province, where it was frequent only in some streams of the Paraná Delta (Pereyra, 1938). Daguerre (1922) indicated it was a very rare species at Rosas (Las Flores district). It is today distributed along a large area in the province, including its southernmost limit, and it is very frequent along the coastal line, where this species increased its abundance at least since the 1990s (Narosky \& Di Giacomo, 1993; Roesler, 2001; Maugeri, 2002; Haene, 2006).

\section{Changes in mammals distribution}

Three mammals species are known to have changed their distributional limits in the last decades (Table 6).

The occurrence in the last decades of some mid- to large mammals, including Dasypus novemcinctus, Cerdocyon thous, and Procyon cancrivorus, in the north of Buenos Aires province was interpreted by some authors as a result of more humid and temperate conditions in the area (Zamorano \& Scillato-Yané, 2008; Fracassi et al., 2010). The latter species was reported by Fracassi et al., (2010) from several localities of the province, including the Reserva Natural Otamendi. This protected area was prospected in high detail during decades in search of mammals (Heinonen de Fortabat \& Chebez, 1997; Pereira et $a l ., 2003)$. Since these researches were unable to find $P$. cancrivorus, the arrival of the species in the area was probably recent (Fracassi et al., 2010).
In the same line, the new records of the micromammals Cryptonanus chacoensis, Deltamys kempi and Oligoryzomys nigripes in more southern localities than previously known (Udrizar Sauthier et al., 2005) may be due to an expansion in their range. Likewise, Holochilus chacarius was first recorded in Buenos Aires in 2004, where it was never found previously (Voglino et al., 2004; Courtalon et al., 2013). Nevertheless these four species were not considered in our study because the extension of their southern distributional limits could also be attributed to lack of historical collections.

\section{DISCUSSION}

This contribution indicates important changes on the geographical distribution of 115 species belonging to seven major groups of plants and animals. Plants, butterflies and birds were the groups with the larger number of southward expansions, with 44, 33, and 24 species respectively, whereas arachnids, mammals and turtles were represented by 8,3 and 3 respectively. In addition, an increase in abundance was detected in a butterfly and some bird taxa. It is worth noting that several of these species have divergent ecological habits. The plants that have expanded their distribution encompass all known kinds of growth represented in riparian forests and marshes from northeastern Argentina and surrounding countries, with the single exception of parasitic plants (Table 7). This fact suggests there is no ecological bias in recently geographically-expanded species. The same may be said for birds, in which insectivorous, frugivorous and piscivorous species have been expanded southward (De La Peña, 2010).

Almost all taxa expanding their southern limits of distribution are inhabitants of SouthAmerican subtropical forests and surrounding wetlands, and show biogeographical affinities with Chaco and Paranaense biogeographical provinces. There are no reports of species from the Pampa or Patagonia biogeographical provinces that had increased their distributional area from south to north in the last decades. On the contrary, some Pampean taxa of Patagonian or Central Argentinean affinities disappeared from several localities and reduced their geographic distribution in the last centuries, mainly due to human disturbance, but also probably due to climatic change (Agnolin \& Lucero, 2014; Teta et al., 2014; Agnolin \& Rivero, 2014). In this regard, some taxa, like the rodent Ctenomys talarum and the birds Sturnella loyca and Geositta 
cunicularia, among others, moved towards more arid and cold regions (Agnolin \& Lucero, 2014; Agnolin \& Rivero, 2014).

With the aim to correlate these changes with the increase in some climatic values during the lasts centuries, it is necessary to rule out other factors that may produce distributional shifts in some species. A main change that occurred in the area of study during late $19^{\text {th }}$ and the $20^{\text {th }}$ centuries is the raise of intensive agriculture, which is clearly not a positive factor for native species (Rapoport, 1996). As stated by Hickling et al. (2006), the use of landscape negatively affects species lacking dispersal abilities to spread over these strongly modified and fragmented habitats.

Human introduction of several exotic tree species in the Pampa grasslands may enable some bird taxa increase their southern limits of geographic distributions (Chimento et al., 2012). Nevertheless, the area here studied had native woods, like the "talares" (Fig. 2), long before the first European explorations (Delucchi \& Charra, 2012)

Probably, colonization of the La Plata River coast by the riparian subtropical rainforest is a climate-driven event (Schnack, 2000). In fact, it was hypothesized that it occurred when the Little Ice Age ended by the mid $19^{\text {th }}$ century (Deschamps et al., 2002; Deschamps \& Tonni, 2007; Guerrero, 2014b). Whenever the time of appearance of riparian forest in the studied area, it is probable that this habitat richness steady increased since the end of $19^{\text {th }}$ century, as noticed early by William H. Hudson (Narosky \& Gallegos, 1992) and Carlos L. Spegazzini (1905). Paraphrasing the last author, northeastern Buenos Aires province flora changed from xerophyte to hygrophyte between 1881 and 1905. Although more evidence is wanting, many species of plants and animals probably arrived from northern locations in that period (Guerrero, 2014b). Among the evidence listed in this paper, the tree Lonchocarpus nitidus could be a good example of those shifts. Most geographical changes listed in the present contribution may have taken place since 1970 to the date, when an important increase in temperature and rainfall has been registered in northern Buenos Aires province (Berbery et al., 2006; Servicio Meteorológico Nacional, 2015). Furthermore, Menéndez (2006) recognized a raise in the discharge of the La Plata Fluvial System over the last four decades. It is well-documented that in almost every raise in this fluvial system level, large masses of floating vegetation (locally called "camalotales") are dragged down and carry lot of individuals and propagules of diverse animal and plant species (Achaval et al., 1979; Guerrero et al., 2012; Katinas et al., 2013). This phenomenon has taken place at least since the colonial period (see e.g. Robertson, 1916), but in most cases, when tropical species arrived to Buenos Aires, they failed to colonize new environments and died due to severe winter temperatures (Spegazzini, 1905; see Hudson commentaries from Narosky \& Gallegos, 1992). Otherwise, the local increase in temperature and humidity, and changes on hydrological parameters since the 1970s, may have enhanced and allowed the possibilities of raft dispersal and effective colonization for many taxa.

\section{CONCLUSIONS}

First, we summarized, analyzed, and discussed the distributional changes of plants and animals detected in recent times in northeastern part of Buenos Aires province, a well-known transitional area between forested galleries of the La Plata Fluvial System and Pampas grasslands. One hundred and fifteen species belonging to different major groups extended their geographical ranges towards southerly locations in northeastern Buenos Aires province by late $20^{\text {th }}$ and early $21^{\text {th }}$ centuries. Geographical extension was detected in species of each reviewed taxonomical group. The changes of geographical distribution limits observed in a large diversity of plant and animal taxa of ecologically divergent groups appear to be coeval with some wellknown climatic changes. Buenos Aires riparian forests as a whole show an incessant increment in species richness and a southward geographical expansion that probably represent ecological responses to climatic changes. Although we summarized distributional changes in well-sampled groups, it is highly probable that a greater part of the flora and fauna is being also affected by the same pattern.

This paper is the first comprehensive analysis demonstrating the possibility of an ecological response of a large number of animals and plants to recent climatic change in Argentina. It is clear that more studies are urgently needed, since most other aspects of the ecological and evolutionary responses to climate change remain largely unknown. 
Table 1: Selected plant species showing distributional changes. LP: La Plata Museum Herbarium, La Plata, Buenos Aires, Argentina; SI: Darwinion Herbarium, San Isidro, Buenos Aires, Argentina. PCSNR: Parque Costero del Sur Natural Reserve. PLNR: Punta Lara Natural Reserve.

\begin{tabular}{|c|c|c|c|c|}
\hline Name & $\begin{array}{l}\text { Southern limit } \\
\text { known in the } 20^{\text {th }} \\
\text { century }\end{array}$ & Source & $\begin{array}{l}\text { Present southern } \\
\text { limit }\end{array}$ & Source \\
\hline $\begin{array}{l}\text { Abutilon pauciflorum A. St.- } \\
\text { Hil. }\end{array}$ & $\begin{array}{l}\text { Northern Buenos } \\
\text { Aires slopes }\end{array}$ & $\begin{array}{l}\text { Cabrera }(1963- \\
1970)\end{array}$ & $\begin{array}{l}\text { Quilmes and } \\
\text { PLNR }\end{array}$ & $\begin{array}{l}\text { Guerrero } 186 \text { (LP); } \\
\text { Moschione \& Klimaitis } \\
\text { (1988) }\end{array}$ \\
\hline $\begin{array}{l}\text { Adiantopsis chlorophylla (Sw.) } \\
\text { Fée }\end{array}$ & Parar & Capurro (1961) & PLNR & Moschione (1987) \\
\hline $\begin{array}{l}\text { Aloysia gratissima (Gillies \& } \\
\text { Hook.) Tronc. }\end{array}$ & $\begin{array}{l}\text { Northern Buenos } \\
\text { Aires slopes }\end{array}$ & $\begin{array}{l}\text { Cabrera }(1963- \\
1970)\end{array}$ & PLNR & $\begin{array}{l}\text { Moschione \& Klimaitis } \\
\text { (1988) }\end{array}$ \\
\hline $\begin{array}{l}\text { Araujia angustifolia (Hook. \& } \\
\text { Arn.) Steud. }\end{array}$ & Paraná Delta & $\begin{array}{l}\text { Cabrera }(1963- \\
1970)\end{array}$ & $\begin{array}{l}\text { PLNR and Berisso } \\
\text { district }\end{array}$ & $\begin{array}{l}\text { Moschione \& Klimaitis } \\
\text { (1988); Guerrero } 471 \\
\text { (LP) }\end{array}$ \\
\hline $\begin{array}{l}\text { Blepharocalyx salicifolius } \\
\text { (Kunth) O. Berg }\end{array}$ & Berisso district & $\begin{array}{l}\text { Cabrera }(1963- \\
1970)\end{array}$ & PCSNR & Guerrero 19 (LP) \\
\hline Canavalia bonariensis Lindl. & Berisso district & $\begin{array}{l}\text { Cabrera }(1963- \\
1970)\end{array}$ & PCSNR & Galup (2009) \\
\hline $\begin{array}{l}\text { Clytostoma callistegioides } \\
\text { (Cham.) Baill. }\end{array}$ & $\begin{array}{l}\text { Punta Lara } \\
\text { Natural Reserve }\end{array}$ & $\begin{array}{l}\text { Cabrera }(1963- \\
1970)\end{array}$ & PCSNR & Galur \\
\hline $\begin{array}{l}\text { Combretum fruticosum } \\
\text { (Loefl.) Stuntz }\end{array}$ & $\begin{array}{l}\text { Entre Ríos pro- } \\
\text { vince }\end{array}$ & $\begin{array}{l}\text { Burkart (1969- } \\
\text { 1987) }\end{array}$ & $\begin{array}{l}\text { Martín García } \\
\text { Island }\end{array}$ & $\begin{array}{l}\text { Lahitte \& Hurrell } \\
\text { (1994) }\end{array}$ \\
\hline Dioscorea sinuata Vell. & $\begin{array}{l}\text { Punta Lara } \\
\text { Natural Reserve }\end{array}$ & $\begin{array}{l}\text { Cabrera }(1963- \\
1970)\end{array}$ & Magdalena district & Guerrero 381 (LP) \\
\hline $\begin{array}{l}\text { Dolichandra cynanchoides } \\
\text { Cham. }\end{array}$ & $\begin{array}{l}\text { Entre Ríos pro- } \\
\text { vince }\end{array}$ & $\begin{array}{l}\text { Burkart (1969- } \\
1987)\end{array}$ & $\begin{array}{l}\text { Costanera Sur } \\
\text { Ecological Reserve }\end{array}$ & $\begin{array}{l}\text { Cabanillas et al. s.n. } \\
\text { (LP) }\end{array}$ \\
\hline $\begin{array}{l}\text { Doryopteris concolor (Langsd. } \\
\text { \& Fisch.) Kuhn }\end{array}$ & $\begin{array}{l}\text { Northern Buenos } \\
\text { Aires slopes and } \\
\text { Martín García } \\
\text { Island }\end{array}$ & $\begin{array}{l}\text { Capurro (1961); } \\
\text { Cabrera (1963- } \\
1970)\end{array}$ & PLNR & Moschione (1987) \\
\hline Doryopteris pedata (L.) Fèe & $\begin{array}{l}\text { Corrientes pro- } \\
\text { vince }\end{array}$ & De la Sota (1977) & $\begin{array}{l}\text { Martín García } \\
\text { Island }\end{array}$ & $\begin{array}{l}\text { Ramos Giacosa et al. } \\
(2004)\end{array}$ \\
\hline $\begin{array}{l}\text { Doryopteris pentagona Pic. } \\
\text { Serm. }\end{array}$ & $\begin{array}{l}\text { Corrientes pro- } \\
\text { vince }\end{array}$ & $\begin{array}{l}\text { Zuloaga et al. } \\
\text { (2008) }\end{array}$ & PLNR & Giudice et al. (2011) \\
\hline $\begin{array}{l}\text { Enterolobium contortisiliquum } \\
\text { (Vell.) Morong }\end{array}$ & Paraná Delta & $\begin{array}{l}\text { Cabrera }(1963- \\
1970)\end{array}$ & $\begin{array}{l}\text { Avellaneda and } \\
\text { Quilmes districts }\end{array}$ & ro et al. (2012) \\
\hline $\begin{array}{l}\text { Gomesa bifolia (Sims) M.W. } \\
\text { Chase \& N.H. Williams }\end{array}$ & $\begin{array}{l}\text { Paraná Delta and } \\
\text { Buenos Aires City }\end{array}$ & $\begin{array}{l}\text { Cabrera }(1963- \\
\text { 1970); Correa et } \\
\text { al. }(2009)\end{array}$ & PLNR and PCSNR & $\begin{array}{l}\text { Tonni s.n. (LP); Cellini } \\
\text { et al. (2009) }\end{array}$ \\
\hline $\begin{array}{l}\text { Heteropterys glabra Hook. \& } \\
\text { Arn. }\end{array}$ & $\begin{array}{l}\text { Paraná Delta and } \\
\text { Buenos Aires City }\end{array}$ & $\begin{array}{l}\text { Cabrera (1963- } \\
1970)\end{array}$ & PLNR & $\begin{array}{l}\text { Moschione \& Klimaitis } \\
\text { (1988) }\end{array}$ \\
\hline $\begin{array}{l}\text { Lonchocarpus nitidus (Vogel.) } \\
\text { Benth. }\end{array}$ & $\begin{array}{l}\text { Entre Ríos pro- } \\
\text { vince }\end{array}$ & Lorentz (1878) & PLNR & $\begin{array}{l}\text { Cabrera \& Dawson } \\
\text { (1944) }\end{array}$ \\
\hline Mimosa pigra L. var. pigra & Paraná Delta & $\begin{array}{l}\text { Cabrera }(1963- \\
1970)\end{array}$ & $\begin{array}{l}\text { Avellaneda and } \\
\text { Quilmes districts }\end{array}$ & Guerrero et al. (2012) \\
\hline Mutisia coccinea A. St.-Hil. & Paraná Delta & $\begin{array}{l}\text { Cabrera }(1963- \\
1970)\end{array}$ & $\begin{array}{l}\text { PLNR and } \\
\text { Magdalena district }\end{array}$ & $\begin{array}{l}\text { Moschione \& Klimaitis } \\
\text { (1988); Galup (2009) }\end{array}$ \\
\hline $\begin{array}{l}\text { Myrceugenia glaucescens } \\
\text { (Cambess.) D. Legrand \& } \\
\text { Kausel }\end{array}$ & Berisso district & $\begin{array}{l}\text { Cabrera }(1963- \\
1970)\end{array}$ & PCSNR & Galup (2009) \\
\hline Osmunda regalis $\mathrm{L}$. & Paraná Delta & Capurro (1961) & PLNR & Moschione (1987) \\
\hline
\end{tabular}




\begin{tabular}{|c|c|c|c|c|}
\hline Name & $\begin{array}{l}\text { Southern limit } \\
\text { known in the } 20^{\text {th }} \\
\text { century }\end{array}$ & Source & $\begin{array}{l}\text { Present southern } \\
\text { limit }\end{array}$ & Source \\
\hline Oxalis hispidula Zucc. & Paraná Delta & $\begin{array}{l}\text { Cabrera (1963- } \\
\text { 1970) }\end{array}$ & PLNR & $\begin{array}{l}\text { Moschione \& Klimaitis } \\
\text { (1988) }\end{array}$ \\
\hline $\begin{array}{l}\text { Passiflora morifolia Mast. in } \\
\text { Mart. }\end{array}$ & $\begin{array}{l}\text { Córdoba, Chaco } \\
\text { and Corrientes } \\
\text { provinces }\end{array}$ & Deginani (2001) & $\begin{array}{l}\text { Berazategui dis- } \\
\text { trict }\end{array}$ & Cellini 78 (SI) \\
\hline $\begin{array}{l}\text { Philodendron tweedieanum } \\
\text { Schott }\end{array}$ & $\begin{array}{l}\text { Entre Ríos pro- } \\
\text { vince }\end{array}$ & $\begin{array}{l}\text { Hurrell \& } \\
\text { Delucchi (2008) }\end{array}$ & PCSNR & $\begin{array}{l}\text { Hurrell \& Delucchi } \\
(2008)\end{array}$ \\
\hline $\begin{array}{l}\text { Phyllanthus sellowianus } \\
\text { (Klotzsch.) Müll. Arg. }\end{array}$ & $\begin{array}{l}\text { Punta Lara } \\
\text { Natural Reserve }\end{array}$ & $\begin{array}{l}\text { Cabrera }(1963- \\
1970)\end{array}$ & PCSNR & Galup (2009) \\
\hline $\begin{array}{l}\text { Pleopeltis minima (Bory) J. } \\
\text { Prado \& R.Y. Hirai }\end{array}$ & Paraná Delta & $\begin{array}{l}\text { Capurro (1961); } \\
\text { Cabrera (1963- } \\
1970)\end{array}$ & $\begin{array}{l}\text { PLNR and La } \\
\text { plata district }\end{array}$ & $\begin{array}{l}\text { Giudice et al. (2011); } \\
\text { Guerrero } 173,519 \text { (LP) }\end{array}$ \\
\hline $\begin{array}{l}\text { Pleopeltis pleopeltifolia } \\
\text { (Raddi) Alston }\end{array}$ & $\begin{array}{l}\text { Corrientes pro- } \\
\text { vince }\end{array}$ & $\begin{array}{l}\text { Zuloaga et al. } \\
(2008)\end{array}$ & $\begin{array}{l}\text { La Plata and } \\
\text { Magdalena district }\end{array}$ & $\begin{array}{l}\text { Guerrero } 172(\mathrm{LP}) \\
\text { Cellini } 22(\mathrm{SI})\end{array}$ \\
\hline $\begin{array}{l}\text { Pouteria salicifolia (Spreng.) } \\
\text { Radlk. }\end{array}$ & Berisso district & $\begin{array}{l}\text { Cabrera }(1963- \\
1970)\end{array}$ & PCSNR & Galup (2009) \\
\hline Psilotum nudum (L.) P. Beauv. & $\begin{array}{l}\text { Corrientes pro- } \\
\text { vince }\end{array}$ & De la Sota (1977) & PLNR & Moschione (1992) \\
\hline $\begin{array}{l}\text { Rumohra adiantiformis (G. } \\
\text { Forst.) Ching }\end{array}$ & $\begin{array}{l}\text { Martín García } \\
\text { Island }\end{array}$ & (1961) & PLNR & Moschione (1987) \\
\hline Sicyos polyacathos Cogn. & $\begin{array}{l}\text { Entre Ríos pro- } \\
\text { vince }\end{array}$ & $\begin{array}{l}\text { Burkart (1969- } \\
\text { 1987) }\end{array}$ & $\begin{array}{l}\text { Avellaneda and } \\
\text { Quilmes districts }\end{array}$ & Guerrero et al. (2012) \\
\hline Solanum sarrachoides Sendtn. & Paraná Delta & $\begin{array}{l}\text { Cabrera }(1963- \\
1970)\end{array}$ & PLNR & $\begin{array}{l}\text { Moschione \& Klimaitis } \\
\text { (1988) }\end{array}$ \\
\hline $\begin{array}{l}\text { Spartina spartinae (Trin.) } \\
\text { Merr. }\end{array}$ & Santa Fe province & $\begin{array}{l}\text { Lewis \& } \\
\text { Collantes (1975) }\end{array}$ & Pergamino district & Lewis \& Pire (2006) \\
\hline $\begin{array}{l}\text { Tarenaya hassleriana } \\
\text { (Chodat) Iltis }\end{array}$ & Paraná Delta & $\begin{array}{l}\text { Cabrera }(1963- \\
1970)\end{array}$ & PLNR & $\begin{array}{l}\text { Moschione \& Klimaitis } \\
\text { (1988) }\end{array}$ \\
\hline Terminalia australis Cambess. & Berisso district & $\begin{array}{l}\text { Cabrera }(1963- \\
1970)\end{array}$ & $\begin{array}{l}\text { Magdalena district } \\
\text { and PCSNR }\end{array}$ & Guerrero 30, $518(\mathrm{LP})$ \\
\hline $\begin{array}{l}\text { Tessaria integrifolia Ruiz \& } \\
\text { Pav. }\end{array}$ & $\begin{array}{l}\text { Paraná Delta and } \\
\text { Buenos Aires City }\end{array}$ & $\begin{array}{l}\text { Hicken }(1910) ; \\
\text { Cabrera (1963- } \\
1970)\end{array}$ & Berisso district & Guerrero 83 (LP) \\
\hline Thelypteris abbiatti C.F. Reed & Ensenada district & Ponce (1987) & Magdalena district & Guerrero 382 (LP) \\
\hline $\begin{array}{l}\text { Thelypteris decurtata subsp. } \\
\text { platense (Weath.) de la Sota }\end{array}$ & Ensenada district & $\begin{array}{l}\text { Capurro (1961); } \\
\text { Ponce (1987) }\end{array}$ & PCSNR & Galup (2009) \\
\hline $\begin{array}{l}\text { Thelypteris hispidula (Decne.) } \\
\text { Reed }\end{array}$ & $\begin{array}{l}\text { Entre Ríos pro- } \\
\text { vince }\end{array}$ & Ponce (1987) & $\begin{array}{l}\text { Ramallo district } \\
\text { and PLNR }\end{array}$ & $\begin{array}{l}\text { Ramos Giacosa et al. } \\
\text { (2004); Giudice et al. } \\
\text { (2011) }\end{array}$ \\
\hline $\begin{array}{l}\text { Thelypteris rivularioides (Fee) } \\
\text { Abbiatti }\end{array}$ & $\begin{array}{l}\text { Entre Ríos pro- } \\
\text { vince }\end{array}$ & Ponce (1987) & PLNR & Moschione (1987) \\
\hline $\begin{array}{l}\text { Thelypteris totta (Thunb.) } \\
\text { Schelpe }\end{array}$ & Paraná Delta & $\begin{array}{l}\text { Capurro (1961); } \\
\text { Cabrera (1963- } \\
1970)\end{array}$ & PLNR & $\begin{array}{l}\text { Ponce (1987); } \\
\text { Moschione (1987) }\end{array}$ \\
\hline $\begin{array}{l}\text { Tillandsia myosura Griseb. } \\
\text { ex Baker }\end{array}$ & $\begin{array}{l}\text { Colonia } \\
\text { Department, } \\
\text { Uruguay }\end{array}$ & $\begin{array}{l}\text { Zuloaga et al. } \\
\text { (2008) }\end{array}$ & PLNR & Cellini et al. (2012) \\
\hline Vicia macrograminea Burkart & Escobar district & $\begin{array}{l}\text { Cabrera }(1963- \\
1970)\end{array}$ & PLNR & $\begin{array}{l}\text { Moschione \& Klimaitis } \\
\text { (1988) }\end{array}$ \\
\hline $\begin{array}{l}\text { Vigna adenantha (G. Mey.) } \\
\text { Maréchal, Mascherpa \& } \\
\text { Stainier }\end{array}$ & $\begin{array}{l}\text { Paraná Delta and } \\
\text { Buenos Aires City }\end{array}$ & $\begin{array}{l}\text { Cabrera }(1963- \\
1970)\end{array}$ & $\begin{array}{l}\text { PLNR and Berisso } \\
\text { district }\end{array}$ & $\begin{array}{l}\text { Moschione \& Klimaitis } \\
\text { (1988); Buet } 233 \text { (LP) }\end{array}$ \\
\hline
\end{tabular}


Table 2: Selected arachnid species showing distributional changes. PCSNR: Parque Costero del Sur Natural Reserve. PLNR: Punta Lara Natural Reserve.

\begin{tabular}{|c|c|c|c|c|}
\hline Name & $\begin{array}{l}\text { Southern limit } \\
\text { known in the } 20^{\text {th }} \\
\text { century }\end{array}$ & Source & $\begin{array}{l}\text { Present southern } \\
\text { limit }\end{array}$ & Source \\
\hline $\begin{array}{l}\text { Discocyrtus prospicuus } \\
\text { (Holmberg, 1876) }\end{array}$ & Berisso district & Ringuelet (1959) & $\begin{array}{l}\text { PCSNR and the } \\
\text { Atlantic seacoast of } \\
\text { the province }\end{array}$ & $\begin{array}{l}\text { Acosta \& Guerrero } \\
(2011)\end{array}$ \\
\hline $\begin{array}{l}\text { Discocyrtus testudineus } \\
\text { (Holmberg, 1876) }\end{array}$ & Paraná Delta & Ringuelet (1959) & $\begin{array}{l}\text { Quilmes and } \\
\text { Berazategui districts }\end{array}$ & $\begin{array}{l}\text { Guerrero et al. } \\
\text { (2012); Guerrero } \\
\text { (2014a) }\end{array}$ \\
\hline $\begin{array}{l}\text { Gryne orensis (Sørensen, } \\
1879 \text { ) }\end{array}$ & Santa Fe province & Ringuelet (1959) & $\begin{array}{l}\text { San Pedro and San } \\
\text { Nicolás districts }\end{array}$ & $\begin{array}{l}\text { Guerrero (2012); } \\
\text { Acosta \& Vergara } \\
(2013)\end{array}$ \\
\hline $\begin{array}{l}\text { Hernandaria scabricula } \\
\text { Sørensen, } 1884\end{array}$ & Berisso district & Ringuelet (1959) & PCSNR & Guerrero (2014a) \\
\hline $\begin{array}{l}\text { Metalibitia argentina } \\
\text { (Sørensen, 1884) }\end{array}$ & $\begin{array}{l}\text { San Nicolás dis- } \\
\text { trict }\end{array}$ & Ringuelet (1959) & PLNR & Guerrero (2011) \\
\hline $\begin{array}{l}\text { Varinodulia insularis Canals, } \\
1935\end{array}$ & $\begin{array}{l}\text { Punta Lara } \\
\text { Natural Reserve }\end{array}$ & Ringuelet (1959) & Berisso district & Guerrero (2014a) \\
\hline $\begin{array}{l}\text { Nephila clavipes (Linnaeus, } \\
1767 \text { ) }\end{array}$ & $\begin{array}{l}\text { Corrientes pro- } \\
\text { vince }\end{array}$ & Levi (1980) & PCSNR & $\begin{array}{l}\text { Guerrero et al. } \\
\text { (2012) }\end{array}$ \\
\hline $\begin{array}{l}\text { Neotrops pombero Grismado } \\
\text { \& Ramírez, } 2013\end{array}$ & $\begin{array}{l}\text { Corrientes pro- } \\
\text { vince }\end{array}$ & $\begin{array}{l}\text { Grismado \& } \\
\text { Ramírez (2013) }\end{array}$ & $\begin{array}{l}\text { Costanera Sur } \\
\text { Ecological Reserve }\end{array}$ & $\begin{array}{l}\text { Grismado \& } \\
\text { Ramírez (2013) }\end{array}$ \\
\hline
\end{tabular}

Table 3: Selected butterfly species showing distributional changes. PCSNR: Parque Costero del Sur Natural Reserve. PLNR: Punta Lara Natural Reserve.

\begin{tabular}{|c|c|c|c|c|}
\hline Name & $\begin{array}{l}\text { Southern limit } \\
\text { known in the } 20^{\text {th }} \\
\text { century }\end{array}$ & Source & Present southern li & Source \\
\hline Adelpha syma (Godart,1884) & Misiones province & Hayward (1973) & PLNR & $\begin{array}{l}\text { Núñez Bustos et } \\
\text { al. (2013) }\end{array}$ \\
\hline Adelpha zea (Hewitson, 1850) & Misiones province & Hayward (1973) & $\begin{array}{l}\text { Paraná Delta and } \\
\text { Costanera Sur } \\
\text { Ecological Reserve }\end{array}$ & $\begin{array}{l}\text { Canals (2000); } \\
\text { Núñez Bustos } \\
\text { (2008) }\end{array}$ \\
\hline $\begin{array}{l}\text { Anarthria jatrophae jatrophae } \\
\text { (Linnaeus, 1763) }\end{array}$ & $\begin{array}{l}\text { Entre Ríos and } \\
\text { Santa Fe provinces }\end{array}$ & Hayward (1973) & PLNR & $\begin{array}{l}\text { Núñez Bustos et } \\
\text { al. (2013) }\end{array}$ \\
\hline $\begin{array}{l}\text { Antigonus liborius areta } \\
\text { Evans, } 1953\end{array}$ & Misiones province & Hayward (1973) & PLNR & $\begin{array}{l}\text { Núñez Bustos et } \\
\text { al. (2013) }\end{array}$ \\
\hline Cymaenes gisca Evans, 1955 & $\begin{array}{l}\text { Northeaster } \\
\text { Argentina }\end{array}$ & Hayward (1973) & PLNR & $\begin{array}{l}\text { Núñez Bustos et } \\
\text { al. (2013) }\end{array}$ \\
\hline $\begin{array}{l}\text { Cymaenes tripunctata } \\
\text { (Latreille, 1823) }\end{array}$ & $\begin{array}{l}\text { Entre Ríos pro- } \\
\text { vince }\end{array}$ & Hayward (1973) & Berisso district & Canals (2000) \\
\hline $\begin{array}{l}\text { Diaethria candrena candrena } \\
\text { (Godart, 1824) }\end{array}$ & Berisso district & Klimaitis (2000) & PCSNR & $\begin{array}{l}\text { Núñez Bustos } \\
\text { (2009) }\end{array}$ \\
\hline $\begin{array}{l}\text { Doxocopa kallina (Godart, } \\
\text { 1824) }\end{array}$ & $\begin{array}{l}\text { Corrientes pro- } \\
\text { vince }\end{array}$ & Hayward (1973) & PLNR & $\begin{array}{l}\text { Núñez Bustos et } \\
\text { al. (2013) }\end{array}$ \\
\hline Eantis thraso (Hübner, 1807) & $\begin{array}{l}\text { Corrientes and } \\
\text { Santa Fe provinces }\end{array}$ & Hayward (1973) & PLNR & $\begin{array}{l}\text { Núñez Bustos et } \\
\text { al. (2013) }\end{array}$ \\
\hline $\begin{array}{l}\text { Emesis lupina melancholica } \\
\text { Stichel, } 1910\end{array}$ & $\begin{array}{l}\text { South Brasil and } \\
\text { Uruguay }\end{array}$ & $\begin{array}{l}\text { Núñez Bustos } \\
(2007)\end{array}$ & PLNR & $\begin{array}{l}\text { Núñez Bustos et } \\
\text { al. (2013) }\end{array}$ \\
\hline
\end{tabular}




\begin{tabular}{|c|c|c|c|c|}
\hline Name & $\begin{array}{l}\text { Southern limit } \\
\text { known in the } 20^{\text {th }} \\
\text { century }\end{array}$ & Source & Present southern limi & Source \\
\hline $\begin{array}{l}\text { Enantia lina psamathe } \\
\text { (Fabricius, 1793) }\end{array}$ & $\begin{array}{l}\text { Paraná Delta and } \\
\text { Martín García } \\
\text { Island }\end{array}$ & $\begin{array}{l}\text { Hayward (1973); } \\
\text { Canals (2000) }\end{array}$ & PLNR & $\begin{array}{l}\text { Núñez Bustos et } \\
\text { al. (2013) }\end{array}$ \\
\hline $\begin{array}{l}\text { Hamadryas februa februa } \\
\text { (Linnaeus, 1823) }\end{array}$ & $\begin{array}{l}\text { Martín García } \\
\text { Island }\end{array}$ & Canals (2000) & PLNR & $\begin{array}{l}\text { Núñez Bustos et } \\
\text { al. (2013) }\end{array}$ \\
\hline $\begin{array}{l}\text { Heraclides astyalus (Godart, } \\
\text { 1819) }\end{array}$ & $\begin{array}{l}\text { Entre Ríos and } \\
\text { Santa Fe provinces }\end{array}$ & Hayward (1973) & PLNR & $\begin{array}{l}\text { Núñez Bustos et } \\
\text { al. (2013) }\end{array}$ \\
\hline $\begin{array}{l}\text { Hermeuptychia hermes } \\
\text { (Fabricius, 1775) }\end{array}$ & $\begin{array}{l}\text { Entre Ríos pro- } \\
\text { vince }\end{array}$ & Hayward (1973) & PLNR & $\begin{array}{l}\text { Núñez Bustos et } \\
\text { al. (2013) }\end{array}$ \\
\hline $\begin{array}{l}\text { Hypanartia bella (Fabricius, } \\
\text { 1793) }\end{array}$ & $\begin{array}{l}\text { Córdoba and } \\
\text { Corrientes pro- } \\
\text { vinces }\end{array}$ & Hayward (1973) & $\begin{array}{l}\text { PCSNR and Atlantic } \\
\text { seacoast }\end{array}$ & $\begin{array}{l}\text { Núñez Bustos } \\
(2009) ; \text { Farina } \\
(2006)\end{array}$ \\
\hline $\begin{array}{l}\text { Lycorea ilione ilione (Cramer, } \\
\text { 1775) }\end{array}$ & $\begin{array}{l}\text { Corrientes pro- } \\
\text { vince }\end{array}$ & Hayward (1973) & PLNR & $\begin{array}{l}\text { Núñez Bustos et } \\
\text { al. (2013) }\end{array}$ \\
\hline $\begin{array}{l}\text { Marpesia chiron marius } \\
\text { (Cramer, 1779) }\end{array}$ & $\begin{array}{l}\text { Corrientes pro- } \\
\text { vince }\end{array}$ & Hayward (1973) & $\begin{array}{l}\text { Costanera Sur } \\
\text { Ecological Reserve }\end{array}$ & $\begin{array}{l}\text { Núñez Bustos } \\
(2008)\end{array}$ \\
\hline $\begin{array}{l}\text { Mechanitis lysimnia lysimnia } \\
\text { (Fabricius, 1793) }\end{array}$ & $\begin{array}{l}\text { Corrientes pro- } \\
\text { vince }\end{array}$ & Hayward (1973) & PCSNR & $\begin{array}{l}\text { Núñez Bustos } \\
(2009)\end{array}$ \\
\hline $\begin{array}{l}\text { Ministrymon una (Hewitson, } \\
\text { 1873) }\end{array}$ & $\begin{array}{l}\text { Misiones and } \\
\text { Formosa provinces }\end{array}$ & Hayward (1973) & $\begin{array}{l}\text { Paraná Delta and } \\
\text { Martín García Island }\end{array}$ & $\begin{array}{l}\text { Núñez Bustos } \\
(2007)\end{array}$ \\
\hline $\begin{array}{l}\text { Monca telata penda (Evans, } \\
\text { 1955) }\end{array}$ & Santa Fe province & Hayward (1973) & Martín García Island & $\begin{array}{l}\text { Núñez Bustos } \\
(2007)\end{array}$ \\
\hline $\begin{array}{l}\text { Morpho epistrophus argentin- } \\
\text { us Frühstorfer, } 1907\end{array}$ & PLNR & Breyer (1939a) & $\begin{array}{l}\text { PCSNR and Atlantic } \\
\text { seacoast }\end{array}$ & $\begin{array}{l}\text { Núñez Bustos } \\
(2009) \text {; Farina } \\
(2006)\end{array}$ \\
\hline Ortilia ithra (Kirby, 1900) & $\begin{array}{l}\text { Entre Ríos and } \\
\text { Santa Fe provinces }\end{array}$ & Hayward (1973) & PCSNR & $\begin{array}{l}\text { Núñez Bustos } \\
(2009)\end{array}$ \\
\hline $\begin{array}{l}\text { Paryphtimoides poltys } \\
\text { (Prittwitz, 1865) }\end{array}$ & Santa Fe province & Hayward (1973) & PLNR & $\begin{array}{l}\text { Núñez Bustos et } \\
\text { al. (2013) }\end{array}$ \\
\hline $\begin{array}{l}\text { Paryphtimoides zeredatha } \\
\text { (Butler, 1869) }\end{array}$ & $\begin{array}{l}\text { Corrientes and } \\
\text { Santa Fe provinces }\end{array}$ & Hayward (1973) & Martín García Island & $\begin{array}{l}\text { Núñez Bustos } \\
(2007)\end{array}$ \\
\hline $\begin{array}{l}\text { Phoebis neocypris neocypris } \\
\text { (Hübner, 1823) }\end{array}$ & $\begin{array}{l}\text { Campana district } \\
\text { and Martín García } \\
\text { Island }\end{array}$ & Canals (2000) & $\begin{array}{l}\text { PCSNR and Atlantic } \\
\text { seacoast }\end{array}$ & $\begin{array}{l}\text { Núñez Bustos } \\
(2009) \text {; Farina } \\
(2006)\end{array}$ \\
\hline $\begin{array}{l}\text { Phoebis sennae marcelina } \\
\text { (Cramer, 1777) }\end{array}$ & PLNR & Canals (2000) & $\begin{array}{l}\text { PCSNR and Atlantic } \\
\text { seacoast }\end{array}$ & $\begin{array}{l}\text { Núñez Bustos } \\
(2009) \text {; Farina } \\
(2006)\end{array}$ \\
\hline $\begin{array}{l}\text { Polites vivex catalina (Plötz, } \\
\text { 1886) }\end{array}$ & $\begin{array}{l}\text { Entre Ríos pro- } \\
\text { vince }\end{array}$ & Hayward (1973) & PLNR & $\begin{array}{l}\text { Núñez Bustos et } \\
\text { al. (2013) }\end{array}$ \\
\hline $\begin{array}{l}\text { Priamides anchisiades capys } \\
\text { (Hübner, 1809) }\end{array}$ & $\begin{array}{l}\text { Entre Ríos and } \\
\text { Santa Fe provinces }\end{array}$ & Hayward (1973) & Berisso district & Canals (2000) \\
\hline $\begin{array}{l}\text { Pyristia nise tenella } \\
\text { (Boisduval, 1836) }\end{array}$ & Córdoba province & Hayward (1973) & PLNR & $\begin{array}{l}\text { Núñez bustos et } \\
\text { al., (2013) }\end{array}$ \\
\hline $\begin{array}{l}\text { Rekoa malina (Hewitson, } \\
\text { 1869) }\end{array}$ & Misiones province & Hayward (1973) & Magdalena district & Canals (2000) \\
\hline $\begin{array}{l}\text { Siproeta epaphus trayja } \\
\text { (Hübner, 1823) }\end{array}$ & $\begin{array}{l}\text { Entre Ríos and } \\
\text { Santa Fe provinces }\end{array}$ & Hayward (1973) & PLNR & $\begin{array}{l}\text { Núñez Bustos et } \\
\text { al. (2013) }\end{array}$ \\
\hline $\begin{array}{l}\text { Strymon canitus (H.H.Druce, } \\
\text { 1907) }\end{array}$ & $\begin{array}{l}\text { Corrientes pro- } \\
\text { vince }\end{array}$ & Hayward (1973) & PLNR & Canals (2000) \\
\hline Urbanus zagorus (Plötz, 1880) & $\begin{array}{l}\text { Corrientes and } \\
\text { Córdoba provinces }\end{array}$ & Hayward (1973) & $\begin{array}{l}\text { Costanera Sur } \\
\text { Ecological Reserve }\end{array}$ & $\begin{array}{l}\text { Núñez Bustos } \\
\text { (2008) }\end{array}$ \\
\hline
\end{tabular}


Table 4: Selected turtle species showing distributional changes. PCSNR: Parque Costero del Sur Natural Reserve.

\begin{tabular}{|c|c|c|c|c|}
\hline Name & $\begin{array}{l}\text { Southern limit known } \\
\text { in the } 20^{\text {th }} \text { century }\end{array}$ & Source & $\begin{array}{l}\text { Present southern } \\
\text { limit }\end{array}$ & Source \\
\hline $\begin{array}{l}\text { Hydromedusa tectifera } \\
\text { Cope, } 1869\end{array}$ & Magdalena district & Cabrera (1998) & PCSNR & $\begin{array}{l}\text { E. L. Guerrero, } \\
\text { pers. obs. }\end{array}$ \\
\hline $\begin{array}{l}\text { Phrynops hilarii (Duméril } \\
\& \text { Bibron, 1835) }\end{array}$ & $\begin{array}{l}\text { Zelaya and Zárate } \\
\text { districts }\end{array}$ & $\begin{array}{l}\text { Williams (1991); Cabrera } \\
\text { (1998) }\end{array}$ & $\begin{array}{l}\text { Magdalena dis- } \\
\text { trict }\end{array}$ & $\begin{array}{l}\text { Derocco et al. } \\
(2005)\end{array}$ \\
\hline $\begin{array}{l}\text { Trachemys dorbignyi } \\
\text { (Duméril \& Bibron, 1835) }\end{array}$ & Entre Ríos province & $\begin{array}{l}\text { Barco \& Larriera (1991); } \\
\text { Richard \& De La Fuente } \\
\text { (1992); Cabrera (1998) }\end{array}$ & $\begin{array}{l}\text { Magdalena dis- } \\
\text { trict }\end{array}$ & $\begin{array}{l}\text { Alcalde } \text { et } a l \text {. } \\
(2012)\end{array}$ \\
\hline
\end{tabular}

Table 5: Selected bird species showing distributional changes. PCSNR: Parque Costero del Sur Natural Reserve. PLNR: Punta Lara Natural Reserve.

\begin{tabular}{|c|c|c|c|c|}
\hline Name & $\begin{array}{l}\text { Southern limit } \\
\text { known in the } 20^{\text {th }} \\
\text { century }\end{array}$ & Source & $\begin{array}{l}\text { Present southern } \\
\text { limit }\end{array}$ & Source \\
\hline $\begin{array}{l}\text { Anhinga anhinga } \\
\text { (Linnaeus, 1766) }\end{array}$ & $\begin{array}{l}\text { Entre Ríos and } \\
\text { Santa Fe provinces }\end{array}$ & Olrog (1963) & Berisso district & $\begin{array}{l}\text { Narosky (1969); } \\
\text { López Lanús \& Roda } \\
\text { (1987) }\end{array}$ \\
\hline $\begin{array}{l}\text { Aramides cajanea Statius- } \\
\text { Muller, } 1776\end{array}$ & $\begin{array}{l}\text { Martín García } \\
\text { Island }\end{array}$ & $\begin{array}{l}\text { Dabbene (1917); } \\
\text { Pereyra (1938) }\end{array}$ & PCSNR & $\begin{array}{l}\text { Pagano \& Merida } \\
(2009)\end{array}$ \\
\hline $\begin{array}{l}\text { Basileuterus leucoblepha- } \\
\text { rus (Vieillot, 1817) }\end{array}$ & $\begin{array}{l}\text { Entre Ríos and } \\
\text { Santa Fe provinces }\end{array}$ & Olrog $(1963,1979)$ & $\begin{array}{l}\text { Quilmes district } \\
\text { and PLNR }\end{array}$ & $\begin{array}{l}\text { Montaldo et al. } \\
\text { (1987); Godoy et al. } \\
\text { (2012) }\end{array}$ \\
\hline $\begin{array}{l}\text { Columbina talpacoti } \\
\text { Temminck, } 1810\end{array}$ & $\begin{array}{l}\text { North Buenos } \\
\text { Aires, i.e. San } \\
\text { Pedro and Ramallo } \\
\text { districts }\end{array}$ & $\begin{array}{l}\text { Hartert \& Venturi } \\
\text { (1909); Pereyra } \\
\text { (1938); Narosky } \\
\text { (1983); Moschione } \text { et } \\
\text { al. (1992); Narosky \& } \\
\text { Di Giacomo (1993); De } \\
\text { La Peña (2013) }\end{array}$ & PLNR & $\begin{array}{l}\text { Bodrati et al. (2006); } \\
\text { Pagano et al. (2012) }\end{array}$ \\
\hline $\begin{array}{l}\text { Crotophaga ani } \\
\text { (Linnaeus, 1758) }\end{array}$ & $\begin{array}{l}\text { Avellaneda dis- } \\
\text { tricts }\end{array}$ & $\begin{array}{l}\text { Hartert \& Venturi } \\
\text { (1909); Olrog (1979) }\end{array}$ & PCSNR & $\begin{array}{l}\text { Pagano \& Merida } \\
(2009)\end{array}$ \\
\hline $\begin{array}{l}\text { Cyanocompsa brisso- } \\
\text { nii (Lichtenstein, 1823) }\end{array}$ & $\begin{array}{l}\text { Santa Fe province } \\
\text { and Paraná Delta }\end{array}$ & $\begin{array}{l}\text { Holmberg }(1898) ; \\
\text { Olrog }(1963,1979)\end{array}$ & PCSNR & $\begin{array}{l}\text { Pagano \& Mérida, } \\
\text { (2009) }\end{array}$ \\
\hline $\begin{array}{l}\text { Elaenia spectabilis } \\
\text { Pelzeln, } 1868\end{array}$ & $\begin{array}{l}\text { Northern Santa Fe } \\
\text { province }\end{array}$ & Olrog $(1963,1979)$ & PCSNR & $\begin{array}{l}\text { Pagano \& Merida } \\
(2009)\end{array}$ \\
\hline $\begin{array}{l}\text { Euscarthmus meloryphus } \\
\text { Wied, } 1831\end{array}$ & $\begin{array}{l}\text { Entre Ríos pro- } \\
\text { vince }\end{array}$ & Olrog (1979) & PLNR & $\begin{array}{l}\text { Povedano \& } \\
\text { Moschione (1989); } \\
\text { Pagano et al. (2012) }\end{array}$ \\
\hline $\begin{array}{l}\text { Hemitriccus mar- } \\
\text { garitaceiventer } \\
\text { (d'Orbigny \& Lafresnaye, } \\
\text { 1837) }\end{array}$ & $\begin{array}{l}\text { Northern Entre } \\
\text { Ríos and Santa Fe } \\
\text { provinces }\end{array}$ & Olrog (1979) & PCSNR & $\begin{array}{l}\text { Pagano \& Merida } \\
(2009)\end{array}$ \\
\hline $\begin{array}{l}\text { Leucochloris albicollis } \\
\text { (Vieillot, 1818) }\end{array}$ & Pilar districts & Pereyra (1965) & $\begin{array}{l}\text { PCSNR and } \\
\text { Atlantic seacoast }\end{array}$ & $\begin{array}{l}\text { Narosky (1983); } \\
\text { Montaldo (1984); } \\
\text { Narosky \& Di Giaco- } \\
\text { mo (1993); Pagano \& } \\
\text { Merida (2009) }\end{array}$ \\
\hline $\begin{array}{l}\text { Melanerpes cactorum } \\
\text { (d'Orbigny, 1840) }\end{array}$ & $\begin{array}{l}\text { Santa Fe and } \\
\text { Entre Ríos pro- } \\
\text { vinces }\end{array}$ & $\begin{array}{l}\text { De La Peña }(2006, \\
\text { 2013) }\end{array}$ & La Plata district & $\begin{array}{l}\text { Chimento et al. (2009, } \\
\text { 2011); Borsellino } \\
\text { (2012) }\end{array}$ \\
\hline
\end{tabular}




\begin{tabular}{|c|c|c|c|c|}
\hline Name & $\begin{array}{l}\text { Southern limit } \\
\text { known in the } 20^{\text {th }} \\
\text { century }\end{array}$ & Source & $\begin{array}{l}\text { Present southern } \\
\text { limit }\end{array}$ & Source \\
\hline $\begin{array}{l}\text { Melanerpes candidus } \\
\text { (Otto, 1796) }\end{array}$ & $\begin{array}{l}\text { North Buenos } \\
\text { Aires province }\end{array}$ & $\begin{array}{l}\text { Hudson (1870); Lynch } \\
\text { Arribálzaga (1878) }\end{array}$ & PCSNR & $\begin{array}{l}\text { Pagano \& Merida } \\
(2009)\end{array}$ \\
\hline $\begin{array}{l}\text { Pachyramphus viridis } \\
\text { (Vieillot, 1816) }\end{array}$ & $\begin{array}{l}\text { Santa Fe and } \\
\text { Corrientes pro- } \\
\text { vinces }\end{array}$ & Olrog (1979) & $\begin{array}{l}\text { Magdalena dis- } \\
\text { trict }\end{array}$ & $\begin{array}{l}\text { Pagano \& Merida } \\
(2009)\end{array}$ \\
\hline $\begin{array}{l}\text { Paroaria capitata } \\
\text { (d'Orbigny \& Lafresnaye, } \\
\text { 1837) }\end{array}$ & $\begin{array}{l}\text { Scarce or absent } \\
\text { in Buenos Aires } \\
\text { province at the } \\
\text { beginnings of the } \\
20^{\text {th }} \text { century }\end{array}$ & $\begin{array}{l}\text { Holmberg (1898); } \\
\text { Burmeister (1868); } \\
\text { Hudson (1870); } \\
\text { Pereyra (1938) }\end{array}$ & $\begin{array}{l}\text { PCSNR and } \\
\text { Atlantic seacoast }\end{array}$ & $\begin{array}{l}\text { Narosky \& Di Giaco- } \\
\text { mo (1993); Pagano } \\
\text { \& Merida (2009); } \\
\text { Chimento et al. }(2012\end{array}$ \\
\hline $\begin{array}{l}\text { Penelope obscura } \\
\text { Temminck, } 1815\end{array}$ & $\begin{array}{l}\text { Corrientes and } \\
\text { Santa Fe provinces }\end{array}$ & Olrog (1963) & $\begin{array}{l}\text { PCSNR and La } \\
\text { Costa district }\end{array}$ & $\begin{array}{l}\text { F.L. Agnolin pers. } \\
\text { obs.; Narosky \& } \\
\text { Yzurieta (2010) }\end{array}$ \\
\hline $\begin{array}{l}\text { Phacellodomus ruber } \\
\text { (Vieillot, 1817) }\end{array}$ & $\begin{array}{l}\text { Santa Fe province. } \\
\text { Accidental in } \\
\text { Avellaneda district } \\
\text { (see text) }\end{array}$ & Olrog $(1963,1979)$ & La Plata district & $\begin{array}{l}\text { Chebez \& Haene } \\
\text { (1991); Narosky \& } \\
\text { Di Giacomo (1993); } \\
\text { Bodrati et al. (2005); } \\
\text { Pagano et al. }(2012)\end{array}$ \\
\hline $\begin{array}{l}\text { Phylloscartes ventralis } \\
\text { (Temminck, 1824) }\end{array}$ & $\begin{array}{l}\text { Entre Ríos pro- } \\
\text { vince }\end{array}$ & Olrog (1979) & PLNR & $\begin{array}{l}\text { Klimaitis \& } \\
\text { Moschione (1987); } \\
\text { Pagano et al. (2012) }\end{array}$ \\
\hline $\begin{array}{l}\text { Picumnus cirratus } \\
\text { Temminck, } 1825\end{array}$ & $\begin{array}{l}\text { Entre Ríos pro- } \\
\text { vince }\end{array}$ & Olrog (1963) & Buenos Aires city & $\begin{array}{l}\text { Narosky \& Di } \\
\text { Giacomo (1993) }\end{array}$ \\
\hline $\begin{array}{l}\text { Saltator similis d'Orbigny } \\
\text { \& Lafresnaye, } 1837\end{array}$ & $\begin{array}{l}\text { Entre Ríos and } \\
\text { Santa Fe provinces }\end{array}$ & Olrog (1979) & $\begin{array}{l}\text { Magdalena dis- } \\
\text { trict }\end{array}$ & Bodrati et al. (2001b) \\
\hline $\begin{array}{l}\text { Sporophila cinnamomea } \\
\text { (Lafresnaye, 1839) }\end{array}$ & $\begin{array}{l}\text { Entre Ríos pro- } \\
\text { vince }\end{array}$ & $\begin{array}{l}\text { Narosky (1973); Olrog } \\
\text { (1979) }\end{array}$ & Buenos Aires City & $\begin{array}{l}\text { Bodrati et al. (1997a); } \\
\text { Pugnali \& Chamorro } \\
\text { (2006) }\end{array}$ \\
\hline $\begin{array}{l}\text { Sporophila hypochroma } \\
\text { Todd, } 1915\end{array}$ & $\begin{array}{l}\text { Entre Ríos pro- } \\
\text { vince }\end{array}$ & $\begin{array}{l}\text { Olrog (1979); Wege \& } \\
\text { Long (1995) }\end{array}$ & Buenos Aires City & $\begin{array}{l}\text { Bodrati et al. (1997b); } \\
\text { Pugnali \& Chamorro } \\
\text { (2006) }\end{array}$ \\
\hline $\begin{array}{l}\text { Tapera naevia (Linnaeus, } \\
\text { 1766) }\end{array}$ & Paraná Delta & Holmberg (1898) & PCSNR & $\begin{array}{l}\text { Pagano \& Merida } \\
(2009)\end{array}$ \\
\hline $\begin{array}{l}\text { Thamnophilus caerules- } \\
\text { cens (Vieillot, 1816) }\end{array}$ & $\begin{array}{l}\text { North Buenos } \\
\text { Aires province }\end{array}$ & $\begin{array}{l}\text { Sclater (1890); } \\
\text { Holmberg } 1898\end{array}$ & Llavallol district & Lucero et al. (2011) \\
\hline $\begin{array}{l}\text { Tigrisoma lineatum } \\
\text { (Boddaert, 1783) }\end{array}$ & $\begin{array}{l}\text { Avellaneda, } \\
\text { Campana and } \\
\text { Escobar districts }\end{array}$ & $\begin{array}{l}\text { Zotta \& Da Fonseca } \\
\text { (1936); Pereyra } \\
\text { (1938); Eisenmann } \\
\text { (1965) }\end{array}$ & PCSNR & $\begin{array}{l}\text { Pagano \& Merida } \\
(2009)\end{array}$ \\
\hline
\end{tabular}

Table 6: Selected mammal species showing distributional changes.

\begin{tabular}{lllll}
\hline Name & $\begin{array}{l}\text { Southern limit } \\
\text { known in the } 20^{\text {th }} \\
\text { century }\end{array}$ & Source & $\begin{array}{l}\text { Present southern } \\
\text { limit }\end{array}$ & Source \\
\hline $\begin{array}{l}\text { Cerdocyon thous } \text { (Linnaeus, } \\
1766)\end{array}$ & $\begin{array}{l}\text { Entre Ríos pro- } \\
\text { vince }\end{array}$ & $\begin{array}{l}\text { Díaz \& Lucherini } \\
(2006)\end{array}$ & $\begin{array}{l}\text { Paraná Delta } \\
\text { (Buenos Aires } \\
\text { province part) }\end{array}$ & $\begin{array}{l}\text { Fracassi } \text { et al. } \\
(2010)\end{array}$ \\
$\begin{array}{l}\text { Dasypus novemcinctus } \\
\text { Linnaeus, } 1758\end{array}$ & $\begin{array}{l}\text { Entre Ríos pro- } \\
\text { vince }\end{array}$ & $\begin{array}{l}\text { Abba \& Vizcaíno } \\
\text { (2008) }\end{array}$ & $\begin{array}{l}\text { Campana and } \\
\text { Zárate districts }\end{array}$ & $\begin{array}{l}\text { Fracassi } \text { et al. } \\
(2010)\end{array}$ \\
1798) & $\begin{array}{l}\text { Entre Ríos pro- } \\
\text { vince }\end{array}$ & $\begin{array}{l}\text { Díaz \& Lucherini } \\
(2006)\end{array}$ & $\begin{array}{l}\text { Campana and } \\
\text { Escobar districts }\end{array}$ & $\begin{array}{l}\text { Fracassi } \text { et al. } \\
(2010)\end{array}$ \\
\hline
\end{tabular}


Table 7: Plant species that expanded their distribution to northern Buenos Aires province and their growth habits.

\begin{tabular}{|c|c|c|c|}
\hline Name & Growth habit & Name & Growth habit \\
\hline Abutilon pauciflorum & Bush & Passiflora morifolia & Climber \\
\hline Adiantopsis chlorophylla & Herb & Philodendron tweedieanum & Herb \\
\hline Aloysia gratissima & Bush & Phyllanthus sellowianus & Bush \\
\hline Araujia angustifolia & Climber & Pleopeltis minima & Epiphyte \\
\hline Blepharocalyx salicifolius & Tree & Pleopeltis pleopeltifolia & Epiphyte \\
\hline Canavalia bonariensis & Climber & Pouteria salicifolia & Tree \\
\hline Clytostoma callistegioides & Climber & Psilotum nudum & Herb \\
\hline Combretum fruticosum & Climber & Rumohra adiantiformis & Herb \\
\hline Dioscorea sinuata & Climber & Sicyos poliacanthos & Climber \\
\hline Dolichandra cynanchoides & Climber & Solanum sarrachoides & Herb \\
\hline Doryopteris concolor & Herb & Spartina spartinae & Herb \\
\hline Doryopteris pedata & Herb & Tarenaya hassleriana & Bush \\
\hline Doryopteris pentagona & Herb & Terminalia australis & Tree \\
\hline $\begin{array}{l}\text { Enterolobium contortisili- } \\
\text { quum }\end{array}$ & Tree & Tessaria integrifolia & Tree \\
\hline Gomesa bifolia & Epiphyte & Thelypteris abbiatti & Herb \\
\hline Heteropterys glabra & Bush & $\begin{array}{l}\text { Thelypteris decurtata subsp. pla- } \\
\text { tense }\end{array}$ & Herb \\
\hline Lonchocarpus nitidus & Tree & Thelypteris hispidula & Herb \\
\hline Mimosa pigra var. pigra & $\begin{array}{l}\text { Bush or small } \\
\text { tree }\end{array}$ & Thelypteris rivularioides & Herb \\
\hline Mutisia coccinea & Climber & Thelypteris totta & Herb \\
\hline Myrceugenia glaucescens & $\begin{array}{l}\text { Bush or small } \\
\text { tree }\end{array}$ & Tillandsia myosura & Epiphyte \\
\hline Osmunda regalis & Herb & Vicia macrograminea & Climber \\
\hline Oxalis hispidula & Herb & Vigna adenantha & Climber \\
\hline
\end{tabular}

\section{ACKNOWLEDGEMENTS}

Thanks to L. Katinas, S.O. Lucero, N.R. Chimento Ortíz, L.G. Pagano, C. Klimaitis, J.F. Klimaitis, L. Pereira, R. Lucero, M. Derguy, F. Brisson Egli, G. Lio, T. Narosky, J.R. Contreras, and J.M. Cellini for sharing their ideas and fruitful comments. We are also grateful to P. Carrión, D. Guerrero, G. Guerrero, F. Suazo Lara, P. Cabanillas and G. Delucchi who helped us in our field trips. We also thank S. Bogan (CFA), L. Iharlegui and L. Katinas (LP), L. Pereira and M. Tassara (MLP-Ar), who allowed studying the collections under their care. Special thanks to J.V. Crisci, who discussed our ideas in every detail and read an early draft of this manuscript.

\section{BIBLIOGRAPHY}

Abba, A.M. \& S.F. Vizcaíno. 2008. Los xenartros (Mammalia: Xenarthra) del Museo Argentino de Ciencias Naturales "Bernardino Rivadavia" y el Museo de La Plata. Contribuciones del Museo Argentino de Ciencias Naturales "Bernardino Rivadavia" 4: 1-37.

Achaval, F., J. González, M. Meneghel \& A. Melgarejo. 1979. Lista comentada del material recogido en costas uruguayas, transportado por camalotes desde el Río Paraná. Acta Zoológica Lilloana 35: 195-200.

Acosta, L.E. 2002. Patrones zoogeográficos de los opiliones argentinos (Arachnida: Opiliones). Revista Ibérica de Aracnología 6: 69-84.

Acosta, L.E. 2014. Bioclimatic profile and potential distribution of the Mesopotamian harvestman Discocyrtus testudineus (Holmberg 1876) 
(Opiliones, Gonyleptidae). Zootaxa 3821(3): 301320.

Acosta, L.E. \& E.L. Guerrero. 2011. Geographical distribution of Discocyrtus prospicuus (Arachnida: Opiliones: Gonyleptidae): Is there a pattern? Zootaxa 3043: 1-24.

Acosta, L.E. \& J. Vergara. 2013. New records and distribution modeling of Gryne orensis (Sørensen) (Opiliones: Cosmetidae) support the Mesopotamian-Yungas disjunction in subtropical Argentina. Zootaxa 3736: 143-158.

Agnolin, F.L. \& S.O. Lucero. 2014. Sobre la presencia de Ctenomys talarum (Rodentia, Ctenomyidae) en el noreste de la provincia de Buenos Aires, Argentina. Historia Natural, tercera serie 3: 77-85.

Agnolin, F.L. \& P. Rivero. 2014. Aves del Delta del Río Paraná en la provincia de Buenos Aires, Argentina. Pp. 118-183 in: Athor, J. (ed.). El Delta Bonaerense - Naturaleza, conservación y patrimonio cultural. Buenos Aires: Fundación de Historia Natural Félix de Azara. 420 pp.

Agnolin, F.L., I. Godoy \& P. Carlini. 2014. Reptiles y anfibios del Delta del Río Paraná en la provincia de Buenos Aires, Argentina. Pp. 184-210 in: Athor, J. (ed.). El Delta Bonaerense - Naturaleza, conservación y patrimonio cultural. Buenos Aires: Fundación de Historia Natural Félix de Azara. 420 pp.

Alcalde, L., N.N. Derocco, S.D. Rosset \& J.D. Williams. 2012. Southernmost localities of Trachemys dorbigni and first record of Trachemys scripta elegans for Argentina (Cryptodira: Emydidae). Chelonian Conservation Biology 11(1): 128-133.

Arturi, M.F. \& M.C. Juárez. 1997. Composición de las comunidades arbóreas de la Isla Martín García en relación a un gradiente ambiental. Ecología Austral 7: 65-72.

Babarskas, M., E. Haene, J. Pereira. 2003. Aves de la Reserva Natural Otamendi. Pp. 47-11 in: Haene, E. \& J. Pereira (eds.). Fauna de Otamendi. Inventario de los animales vertebrados de la Reserva Natural Otamendi. Serie: Temas de Naturaleza y Conservación, Monografía 3. Buenos Aires: Aves Argentinas /Asociación Ornitológica del Plata. 191 pp.

Barbetti, R., A. Ronchetti \& J.C. Chebez. 1985. Refugio Educativo de la Ribera Norte, partido de San Isidro, provincia de Buenos Aires. Buenos Aires: Fundación Vida Silvestre Argentina. 54 pp.

Barco D.M. \& A. Larriera. 1991. Sobre la validez de las subespecies de Trachemys dorbigni y su distribucion geográfica (Reptilia, Chelonia, Emydinae). Revista de la Asociación de Ciencias Naturales del Litoral 22(2): 11-17.

Barros, V.R., J.A. Boninsegna, I.A. Camilloni, M. Chidiak, G.O. Magrín \& M. Rusticucci. 2015. Climate change in Argentina: trends, projections, impacts and adaptation. Wiley Interdisciplinary Reviews: Climate Change 6(2): 151-169.

Berbery, E.H., M. Doyle \& V. Barros. 2006. Tendencias regionales en la precipitación. Pp. 67-79 in: Barros, V., R. Clarke \& P. Silva Días (eds.). El cambio climático en la Cuenca del Plata. Buenos Aires: CONICET. 232 pp.

Bodrati, A. 2001. Notas sobre aves infrecuentes o poco conocidas para la Provincia de Buenos Aires, Argentina. Nuestras Aves 41: 13-17.

Bodrati, A. \& E. Sierra. 2009. Nuevos aportes sobre la colonización austral del Pepitero Verdoso (Saltator similis) en las provincias de Buenos Aires y Entre Ríos, Argentina. Nuestras Aves 53: 29-30.

Bodrati, A., C. Henschke \& C. Nardini. 1997a. Nuevas citas del género Sporophila para Buenos Aires, Argentina. Nuestras Aves 37: 5.

Bodrati, A., G. Bodrati, C. Ferrari, E. Mérida \& E. Haene. 1997b. Notas sobre la avifauna del Baradero, provincia de Buenos Aires, Argentina. Nuestras Aves 37: 2-4.

Bodrati, A., G. Bodrati \& H. Fernández. 2001a. Notas sobre la avifauna del norte de la provincia de Buenos Aires, Argentina. Nuestras Aves 41:17-21

Bodrati, A., C. Ferrari, E. Bordón, D. Novoa \& R. Romero Huergo. 2001b. El Pepitero Verdoso (Saltator similis) en la provincia de Buenos Aires. Nuestras Aves 41: 29.

Bodrati A., E. Mérida \& E. Sierra. 2005. Vuelta de Obligado. Pp. 37-38 in Di Giacomo, A.S. (ed.). Áreas importantes para la conservación de las aves en Argentina. Sitios prioritarios para la conservación de la biodiversidad. Serie: Temas de Naturaleza y Conservación, Monografía 5. Buenos Aires: Aves Argentinas/Asociación Ornitológica del Plata. 514 páginas.

Bodrati A., E. Mérida, G. Bodrati \& E. Sierra. 2006. Avifauna del talar de Vuelta de Obligado y sus ambientes contiguos. San Pedro, provincia de Buenos Aires, Argentina. Pp. 117-124 in: Mérida, E. \& J. Athor (eds.). Talares bonaerenses y su conservación. Buenos Aires: Fundación de Historia Natural Félix de Azara. 262 pp.

Borsellino, L. 2012. Nuevo registro del Carpintero del Cardón (Melanerpes cactorum) en la Ciudad Autónoma de Buenos Aires, Argentina. Nótulas Faunísticas 110: 1-2.

Breyer, A. 1939a. Los representantes argentinos de la familia Morphidae. Physis 17: 503-508.

Breyer, A. 1939b. Lepidopterología argentina. Consideraciones zoogeográficas. Physis 17: 509525.

Burkart, A. (ed.). 1969-1987. Flora ilustrada de Entre Ríos (Argentina), parts 1-6. Buenos Aires: INTA, Colección Científica.

Burkart, R., N. Bárbaro, R.O. Sánchez \& D.A. Gómez. 1999. Eco-regiones de la Argentina. Buenos Aires: Administración de Parques Nacionales. 42 pp.

Burmeister, H. 1868. Contributions to the ornithology of the Argentine Republic and adjacent lands. Proceedings of the Zoological Society of London 1868: 633-636.

Cabrera, A.L. (ed.) 1963-1970. Flora de la provincia de Buenos Aires, parts 1-6. Buenos Aires: INTA, Colección Científica.

Cabrera, A.L. 1971. Fitogeografía de la República Argentina. Boletín de la Sociedad Argentina de 
Botánica 14(1-2): 1-42.

Cabrera, A.L. \& G. Dawson. 1944. La selva marginal de Punta Lara en la ribera argentina del Río de La Plata. Revista del Museo de La Plata, Botánica 22: 1-382.

Cabrera, M.R. 1998. Las tortugas continentales de Sudamérica austral. Córdoba (Argentina): Privately printed. $108 \mathrm{pp}$.

Cameron, G.N. \& D. Scheel. 2001. Getting warmer: Effect of global climate change on distribution of rodents in Texas. Journal of Mammalogy 82: 652680.

Canals, G.R. 2000. Mariposas bonaerenses. Buenos Aires: LOLA. 347 pp.

Capurro, R. 1961. Las Pteridofitas de la provincia de Buenos Aires e Isla Martín García. Anales de la Comiión de Investigaciones Científicas de la Provincia de Buenos Aires 3: 55-323.

Cei, J.M. 1993. Reptiles del noroeste, nordeste y este de la Argentina. Herpetofauna de las selvas subtropicales, Puna y Pampas. Museo Regionale di Scienze Naturali (Torino) 14: 1-949.

Cellini, J.M., L. Salomón, R. García, L. Cellini, L. Cellini \& M. Sánchez. 2009. Limite sur del área de distribución de Oncidium bifolium Sims. (Orchidaceae). Boletín de la Sociedad Argentina de Botánica 44 (Supl.): 83.

Cellini, J.M., L. Salomón \& S. Donadío. 2012. Tillandsia myosura Griseb. ex Baker (Bromeliaceae), una nueva cita para la provincia de Buenos Aires (Argentina). Bonplandia (Corrientes) 21(2): 183188.

Césari, C. \& P. Alonso. 1975. Presencia en el Delta Bonaerense de la Pava de Monte Común. Hornero 11: $307-308$

Chebez, 2009. Otros que se van. Fauna Argentina Amenazada. Buenos Aires: Albatros: 552 pp.

Chebez, J.C. \& E. Haene. 1991. Un refugio natural de los bosques nativos de tala y bajos ribereños vecinos de Ramallo, provincia de Buenos Aires, Argentina. Buenos Aires: Administración de Parques Nacionales. 22 pp.

Chimento, N.R., F.L. Agnolin, R.F. Lucero \& R. Obredor. 2009. Nidificación del Carpintero del Cardón (Melanerpes cactorum) en la provincia de Buenos Aires, Argentina. Nótulas Faunísticas 37: 1-3.

Chimento, N.R., J. La Grotteria, F.L. Agnolin \& R.F. Lucero. 2011. Nuevos registros del carpintero del cardón (Melanerpes cactorum) en la provincia de Buenos Aires, Argentina. Historia Natural, tercera serie 1: 95-99.

Chimento, N.R., F.L. Agnolin, E.L. Guerrero, A.M. López \& R.F. Lucero. 2012. Nuevos registros de aves y consideraciones sobre la extensión geográfica de los talares al sur de la provincia de Buenos Aires. Nótulas Faunísticas 89: 1-12.

Correa, M.N., M. Sánchez \& J.A. Hurrell. 2009. Orchidaceae. Pp. 327-390 in Hurrell, J.A. (director). Flora Rioplatense. Parte 3: Monocotiledóneas. Vol. 4: Asparagales, Dioscoreales, Liliales. Buenos Aires: LOLA.

Courtalon, P., G. Lo Coco \& R.F. Bó. 2013. Presencia de Holochilus chacarius Thomas, 1906 (Mammalia, Rodentia, Sigmodontinae) en el Delta Medio del Río Paraná, Entre Ríos, Argentina. Revista del Museo Argentino de Ciencias Naturales "Bernardino Rivadavia”, nueva serie 15(2): 289-293.

Crick, H.Q.P. \& T.H. Sparks. 1999. Climatic change related to egg-laying trends. Nature 399: 423-424.

Dabbene, R. 1917. Notas sobre una colección de aves de la isla de Martín García (Parte $1^{\mathrm{a}}$ ). Hornero 1: 29-34.

Daguerre, J.B. 1922. Lista de aves coleccionadas y observadas en Rosas F.C.S. Hornero 2: 259-271.

Dascanio, L. M. \& S.E. Ricci. 1988. Descripción florístico-estructural de las fisonomías dominadas por árboles en la Reserva Integral de Punta Lara (Provincia de Buenos Aires, República Argentina). Revista del Museo de La Plata, Botánica 97(14): 191-206.

Deginani, N.B. 2001. Las especies argentinas del género Passiflora (Passifloraceae). Darwiniana 39(1-2): 43-129.

De la Peña, M.R. 2006. Lista y distribución de las aves de Santa Fe y Entre Ríos. Buenos Aires: LOLA. 164 pp.

De la Peña, 2010. Los alimentos de las aves. Santa Fe: Universidad Nacional del Litoral. CD-ROM.

De la Peña, 2013. Citas, observaciones y distribución de aves argentinas. Edición ampliada. Serie: Naturaleza, Conservación, y Sociedad № 7, Buenos Aires: Ediciones Biológica. 786 pp.

De la Sota, E. 1977. Pteridophyta. In: Cabrera, A.L. (director). Flora de la provincia de Jujuy, República Argentina. Parte 2. Buenos Aires: INTA, Colección Científica. 275 pp.

Delucchi, G. \& G. Charra. 2012. La flora y vegetación pampeanos vistas por los cronistas y viajeros de los siglos XVIII y XIX. Historia Natural, tercera serie 2(1):73-83.

Derocco, N.N., L. Alcalde \& S.D. Rosset. 2005. Ampliación de la distribución de Phrynops hilarii (Pleurodira: Chelidae) en Argentina. Cuadernos de Herpetología 19(1): 63.

Deschamps, J.R. \& E.P. Tonni. 2007. Aspectos ambientales en torno al primer fuerte de la frontera sur de Buenos Aires: "El Zanjón” 1745-1779. Documentos de trabajo. Universidad de Belgrano 175: 1-24.

Deschamps, J.R., O. Otero \& E.P. Tonni. 2003. Cambio climático en la pampa bonaerense: las precipitaciones desde los siglos XVIII al XX. Documentos de Trabajo, Universidad de Belgrano 109: 1-18.

Díaz, M.M. \& M. Lucherini. 2006. Orden Carnivora. Familia Canidae. Pp. 89-83 in: Barquez, R.M., M.M. Díaz \& R.A. Ojeda (eds.). Los mamíferos de Argentina: Sistemática y distribución. Mendoza: SAREM. 356 pp.

Di Pietro, D.O., L. Alcalde, J.D. Williams \& M.R. Cabrera. 2012. Geographic distribution: Hydromedusa tectifera (South American snake-necked turtle). Herpetology Review 43: 303.

d'Orbigny, A. 1847. Voyage dans l'Amérique méridionale. Volume 9. París: Pitois-Levrault. 567 pp.

Doumecq Milieu, R.E., A. Morici \& N.A. Nigro. 2012. 
Ampliación de la distribución austral del carpincho (Hydrochoerus hydrochaeris) en la provincia de Buenos Aires, Argentina. Nótulas Faunísticas 92: 1-10.

Eguía, R. 2012. Una pava de monte en Villa Ortúzar. Available in: http://ciudadsilvestre.blogspot.com. ar/2012/12/una-pava-de-monte-en-villa-ortuza. html

Eisenmann, E. 1965. The tiger-herons (Tigrisoma) of Argentina. Hornero 10: 225-234.

Farina, J.L. 2006. Insectos asociados al tala (Celtis tala), en el límite sur del espinal. Pp. 166-172 in: Mérida, E. \& J. Athor (eds.). Talares bonaerenses y su conservación. Buenos Aires: Fundación de Historia Natural Félix de Azara. 262 pp.

Fernández, H.G. 1991. Nuevas aves para la provincia de Buenos Aires. Nuestras Aves 24: 26.

Fracassi, N.G., P.A. Moreyra, B. Lartigau, P. Teta, R. Landó \& J.A. Pereira. 2010. Nuevas especies de mamíferos para el bajo Delta del Paraná y bajíos ribereños adyacentes, Buenos Aires, Argentina. Mastozoología Neotropical 17(2): 367-373.

Freiberg, M.A. 1977. Reptilia: Testudines o Chelonia. In: Ringuelet, R.A. (ed.). Fauna de agua dulce de la República Argentina. Vol. 42 (1). Buenos Aires: FECIC. 55 pp.

Galliari, C.A., W.D. Berman \& F.J. Goin. 1991. Mamíferos. Pp. 3-35 in: Goin, F. \& R. Goñi (eds.). Situación ambiental de la provincia de Buenos Aires. Recursos y rasgos naturales en la evaluación ambiental. Vol. 1(5). La Plata: Comisión de Investigaciones Científicas de la Provincia de Buenos Aires.

Gallardo, J.M. 1977. Reptiles de los alrededores de Buenos Aires. Buenos Aires: Eudeba. 213 pp.

Galup, A. 2009. Proyecto Monte Nativo. Pp. 429-452 in: Athor J. (ed.). Parque Costero del Sur. Naturaleza, Conservación y Patrimonio Natural. Buenos Aires: Fundación de Historia Natural Félix de Azara. 496 pp.

Giudice, G.E., J.P. Ramos Giacosa, M.L. Luna, A. Yáñez \& E.R. de la Sota. 2011. Diversidad de helechos y licófitas de la Reserva Natural Punta Lara, Buenos Aires, Argentina. Revista de Biología Tropical 59(3): 1037-1046.

Godoy, I., F. Suazo Lara, E.L. Guerrero, P. Rivero, B. González, M. Alegre, A. Godoy, C. Kain, F.G. Sesto \& N.R. Chimento. 2012. Relevamiento biótico de la costa rioplatense de los partidos de Quilmes y Avellaneda (Buenos Aires, Argentina). Parte II: Aves. Historia Natural, tercera serie 2(2): 57-94.

Grilli, P. \& J.I. Areta. 2002. Nuevos registros de Anambé Verdoso (Pachyramphus viridis) en la provincia de Buenos Aires. Nuestras Aves 46: 28.

Grismado, C.J. \& M.J. Ramírez. 2013. The New World goblin spiders of the new genus Neotrops (Araneae: Oonopidae), Part 1. Bulletin of the American Museum of Natural History 383: 1-150.

Guerrero, E.L. 2011. Riqueza específica en una taxocenosis de Opiliones (Arachnida) en la localidad de Lima, provincia de Buenos Aires, Argentina. Historia Natural, tercera serie 1: 35-45.
Guerrero, E.L. 2012. Notas sobre la distribución geográfica de Gryne orensis (Arachnida, Opiliones, Cosmetidae) en la República Argentina. Historia Natural, tercera serie 2(1): 85-93.

Guerrero, E.L. 2014a. Modificaciones recientes en la distribución geográfica de opiliones (Arachnida) mesopotámicos en la provincia de Buenos Aires, Argentina, y su relación con el cambio climático. Historia Natural, tercera serie 4(1): 85-104.

Guerrero, E.L. 2014b. El paradigma del relicto de selva marginal y las políticas de conservación de bosques nativos en el noreste de la provincia de Buenos Aires: Una revisión crítica. Trabajo ganador del concurso Vale La Pena 2014, IPID, Buenos Aires. 35 pp. Available in: http://ipidar.org/el-paradigmadel-relicto-de-selva-marginal-y-las-politicas-deconservacion-de-bosques-nativos-en-el-noreste-dela-provincia-de-buenos-aires-una-revision-critical

Guerrero, E.L., F. Suazo Lara, N.R. Chimento, F. Buet \& P. Simón. 2012. Relevamiento biótico de la costa rioplatense de los partidos de Quilmes y Avellaneda (Buenos Aires, Argentina). Parte I: Aspectos ambientales, botánicos y fauna de Opiliones (Arachnida), Mygalomorphae (Arachnida) y Chilopoda (Myriapoda). Historia Natural, tercera serie 2(2): 31-56.

Haene, E. 2006. Invasión de loros en la ciudad. Naturaleza y Conservación 19: 16-23.

Hartert, E. \& S.Venturi 1909. Notes sur les oiseaux de la République Argentine. Novitates Zoologicae 16: 159-267.

Hayward, K.J. 1973. Catálogo de los ropaloceros argentinos. Opera Lilloana 23: 1-318.

Heinonen Fortabat, S. \& J.C. Chebez. 1997. Los Mamíferos de los Parques Nacionales de la Argentina. LOLA, Buenos Aires (Argentina), 76 pp.

Hicken, C.M. 1910. Chloris platensis argentina. Apuntes de Historia Natural 2: 3-292.

Hickling, R., D.B. Roy, J.K. Hill, R. Fox \& C.D. Thomas. 2006. The distributions of a wide range of taxonomic groups are expanding polewards. Global Change Biology 12: 450-455.

Holmberg, E.L. 1878. Viaje al río Luján. El Naturalista Argentino 1: 243-263.

Holmberg, E.L. 1898. Fauna de la República Argentina: Aves. Segundo Censo de la República Argentina 1: 494-574.

Hudson, W.H. 1870. First letter on the ornithology of Buenos Aires. Proceedings of the Zoological Society of London 1870: 87-89.

Hurrell, J.A. \& G. Delucchi. 2008. Araceae. Pp. 3990 in Hurrell, J.A. (director). Flora Rioplatense. Parte 3: Monocotiledóneas. Vol. 1: Asparagales, Dioscoreales, Liliales. Buenos Aires: LOLA.

Katinas, L., J.V. Crisci, P. Hoch, M.C. Tellería \& M.J. Apodaca. 2013. Trans-oceanic dispersal and evolution of early composites (Asteraceae). Perspectives in Plant Ecology, Evolution and Systematics 15(5): 269-280.

Klimaitis, J.F. 2000. Cien Mariposas. Buenos Aires: Albatros. 128 pp. 
Klimaitis, J.F. \& F.N. Moschione. 1987. Aves de la Reserva Integral de Selva Marginal de Punta Lara $y$ sus alrededores. Buenos Aires: Ministerio de Economía de la Provincia de Buenos Aires. 156 pp.

Kocsis, M. \& L. Hufnagel. 2011. Impacts of climate change on Lepidoptera species and communities. Applied Ecology and Environmental Research 9(1): 43-72.

Krapovickas, S., A. Di Giacomo, M. Babarskas \& A. Di Giacomo. 1992. Aves silvestres de la Reserva Natural Estricta Otamendi. Lista sistemática. Buenos Aires: Administración de Parques Nacionales y Municipalidad de Campana. $7 \mathrm{pp}$.

Lahitte, H.B. \& J.A. Hurrell. 1994. Flora arbórea y arborescente de la Isla Martín García nativas y naturalizadas. Comisión de Investigaciones Científicas, Serie Informe 47. 229 pp.

Levi, H.S. 1980. The orb weaber genus Mecynogea, the subfamily Metinae and the genera Pachygnatha, Glenognatha and Azilia of the subfamily Tetragnathidae north of Mexico (Araneae, Araneidae). Bulletin of the Museum of Comparative Zoology 149(1): 1-74.

Levi, H.S. 1985. The spiny orb-weaber Micrathena and Chaetacis (Araneae: Araneidae). Bulletin of the Museum of Comparative Zoology 150(8): 429-618.

Lewis, J.P. \& M.B. Collantes. 1975. La vegetación de la provincia de Santa Fe. II. Las comunidades vegetales del departamento de Rosario. Boletín de la Sociedad Argentina de Botánica 16: 151-179.

Lewis, J.P. \& E. Pire. 2006. Nótula sobre Spartina argentinensis Parodi (Poaceae) en la flora bonaerense. Revista de Investigaciones de la Facultad de Ciencias Agrarias, Universidad Nacional de Rosario 8: 67-68.

López Lanús, B. \& M.A. Roda. 1987. Nidificación de Anhinga anhinga en la Provincia de Buenos Aires. Nuestras Aves 5(12): 13-14.

Lorentz, P.G. 1878. La vegetación del nordeste de la provincia de Entre Ríos: Informe científico. Buenos Aires: Imprenta El Economista. 179 pp.

Lucero, R.F., F.L. Agnolin, S. Lucero \& M.C. Molina. 2011. Fauna de la Reserva Micológica "Dr. Carlos Spegazzini”, partido de Lomas de Zamora, Buenos Aires, Argentina. Parte I: Mammalia-Aves. Historia Natural, tercera serie 1: 65-94.

Lynch Arribálzaga, E. 1878. Rápida ojeada sobre la fauna de Baradero. El Naturalista Argentino1: 1-18.

Marelli, C.A. 1924. Elenco sistemático de la fauna de la provincia de Buenos Aires. Memorias del Ministerio de Obras Públicas 1922-1923: 597-665.

Maugeri, F.G. 2002. Aves nuevas o poco conocidas para el sudoeste de la provincia de Buenos Aires, Argentina. Nuestras Aves 44: 16-19.

Maugeri, F.G. \& M.J. Montenegro. 2002. Tres nuevas citas de aves para la provincia de Buenos Aires, Argentina. Nuestras Aves 43: 21-22

McCarty, J.P. 2001. Ecological consequences of recent climate change. Conservation Biology 15(2): 320331.

Medone, P., S. Ceccarelli, P.E. Parham, A. Figuera \& J.E. Rabinovich. 2015. The impact of climate change on the geographical distribution of two vectors of Chagas disease: implications for the force of infection. Philosophical Transactions of the Royal Society of London B: Biological Sciences 370(1665): $1-12$.

Menéndez, A. 2006. Tendencias hidrológicas en la Cuenca del Plata. Pp. 81-92 in: Barros, V., R. Clarke \& P. Silva Días (eds.). El cambio climático en la Cuenca del Plata. Buenos Aires: CONICET. $232 \mathrm{pp}$.

Mérida, E. \& A. Bodrati. 2006. Consideraciones sobre la conservación de los talares de barranca del nordeste de Buenos Aires y descripción de las características de un relicto en Baradero. Pp. 71-82 in: Mérida, E. \& J. Athor (eds.). Talares bonaerenses y su conservación. Buenos Aires: Fundación de Historia Natural Félix de Azara. 262 pp.

Montaldo, N.H. 1984. Asociación de dos especies de picaflores con árboles del género Eucalyptus (Myrtaceae) en la Provincia de Buenos Aires. Hornero 12(3): 159-162.

Montaldo, N.H., A.A. Chiappe \& G.G. Roitman. 1987. Basileuterus leucoblepharus (Vieillot) en Buenos Aires. Registro en Punta Lara y comentarios sobre su presencia en la provincia. Historia Natural 7: 1-3.

Moschione, F.N. 1987. Ampliación de la distribución de seis especies de helechos (Pteridophyta, Filicopsida) en la ribera argentina del Río de La Plata. Garganchillo 1(3): 7-13.

Moschione, F.N. 1992. Hallazgo de la Varita de San Antonio Psilotum nudum (Psilotaceae) en Punta Lara, provincia de Buenos Aires. Garganchillo 12: 8-10.

Moschione, F.N. \& J.F. Klimaitis.1988. Flora de Punta Lara. Cartilla sistemática de los vegetales superiores de la Reserva de Selva Marginal de Punta Lara y alrededores (provincia de Buenos Aires). Buenos Aires: Grupo de Observadores Ribereños de Aves. 14 pp.

Moschione, F.N., J. San Cristobal \& I. Barrios. 1992. Nuevos registros de la Torcacita Colorada, Columbina talpacoti en la provincia de Buenos Aires. Garganchillo 6(12): 7-8.

Morrone, J.J. 2014. Biogeographical regionalization of the Neotropical region. Zootaxa 3782(1): 1-110.

Narosky, T. 1969. Presencia de Anhinga anhinga en la Provincia de Buenos Aires. Hornero 11(1): 57.

Narosky, T. 1973. Una nueva especie de Sporophila para la avifauna argentina, basado en estudios de campo y material coleccionado por el Dr. R. Zelich, de Pronunciamiento, Entre Ríos. Hornero 11(3): 169-171.

Narosky, T. 1983. Registros nuevos o infrecuentes de aves argentinas. Hornero 12(2): 122-126.

Narosky, T. 2012. Las aves del Buenos Aires de ayer. Pp. 199-214 in: Athor, J. (ed.). Buenos Aires, la Historia de su paisaje natural. Buenos Aires: Fundación de Historia Natural Félix de Azara. 480 pp.

Narosky, T. \& A.G. Di Giácomo. 1993. Las Aves de la Provincia de Buenos Aires. Buenos Aires: Asociación Ornitológica del Plata / Vázquez Mazzini. 78 pp. 
Narosky, T. \& D. Gallegos. 1992. Las aves de la pampa perdida. Una versión crítica de la obra ornitológica de Guillermo Enrique Hudson. Buenos Aires: Asociación Ornitológica del Plata / Asociación Antorchas. 126 pp.

Narosky, T. \& D. Yzurieta. 2010. Guía para la identificación de las aves de Argentina y Uruguay. $16^{\text {th }}$ edition. Buenos Aires: Vázquez Mazzini. 432 pp.

Narosky, T., C. Henschke \& D. Yzurieta. 1996. Aves de Costanera Sur y Ciudad de Buenos Aires. Guía para su reconocimiento. Buenos Aires: Vázquez Mazzini. $71 \mathrm{pp}$.

Nores, M., M.M. Cerana \& D.A. Serra. 2005. Dispersal of forest birds and trees along the Uruguay River in southern South America. Diversity and Distributions 11: 205-217.

Nori, J., P.A. Carrasco \& G.C. Leynaud. 2013. Venomous snakes and climate change: ophidism as a dynamic problem. Climate Change 122(1-2): 67-80.

Núñez Bustos, E. 2007. Biogeografía de los Rhopalocera de la Isla Martín García, provincia de Buenos Aires, Argentina (Lepidoptera: Papilionoidea y Hesperioidea).SHILAP.Revista de Lepidopterología 35(139): 289-309.

Núñez Bustos, E. 2008. Las especies urbanas de Rhopalocera de la Reserva Ecológica Costanera Sur, Ciudad de Buenos Aires, Argentina (Lepidoptera: Hesperioidea y Papilionoidea). SHILAP. Revista de Lepidopterología 36(144): 435-447.

Núñez Bustos, E. 2009. La fauna de mariposas (Insecta: Lepidoptera) del Parque Costero del Sur (Partidos de Magdalena y Punta Indio), Provincia de Buenos Aires, Argentina. Pp. 278-294 in: Athor J. (ed.). Parque Costero del Sur. Naturaleza, Conservación y Patrimonio Natural. Buenos Aires: Fundación de Historia Natural Félix de Azara. 496 pp.

Núñez Bustos, E., J.F. Klimaitis, C. Klimaitis \& F.N.Moschione. 2013. Mariposas diurnas (Lepidoptera: Papilionoidea y Hesperioidea) del relicto de selva paranaense más austral del mundo: la Reserva Natural Integral Punta Lara, provincia de Buenos Aires, Argentina. Historia Natural, tercera serie 3(1): 87-97.

Olrog, C.C. 1963. Lista y distribución de las aves argentinas. Opera Lilloana 9:1-377.

Olrog, C.C. 1979. Nueva Lista de la avifauna argentina. Opera Lilloana 27: 1-324.

Pagano, L.G. \& E. Mérida. 2009. Aves del Parque Costero del Sur. Pp. 200-244 Athor J. (ed.). Parque Costero del Sur. Naturaleza, Conservación y Patrimonio Natural. Buenos Aires: Fundación de Historia Natural Félix de Azara. 496 pp.

Pagano, L.G., E. Jordan, J.I. Areta, R.F. Jense \& I. Roesler. 2012. Aves de la Reserva Natural de Punta Lara. Pp. 89-135 in: Roesler, I. \& M.G. Agostini (eds.). Inventario de los vertebrados de la Reserva Natural Punta Lara, provincia de Buenos Aires, Argentina. Serie: Temas de Naturaleza y Conservación, Monografía 8. Buenos Aires: Aves Argentinas /Asociación Ornitológica del Plata. 200 pp.

Pardiñas, U.F.J., P. Teta \& D. Bilenca. 2010. Roedores sigmodontinos de la Región Pampeana: una introducción zoogeográfica. Pp. 37-57 in: Polop, J. \& M. Busch (eds.). Biología y ecología de pequeños roedores en la región pampeana de Argentina. Córdoba (Argentina): Editorial UNCOR. 332 pp.

Parmesan, C. 2006. Ecological and evolutionary responses to recent climate change. Annual Review of Ecology, Evolution, and Systematics 37: 637-669.

Parodi, L.R. 1940. La distribución geográfica de los talares en la Provincia de Buenos Aires. Darwiniana 4: 33-56.

Pereira, J. \& E. Haene. 2003. Reptiles de la Reserva Natural Otamendi. Pp. 37-46 in: Haene, E. \& J. Pereira (eds.). Fauna de Otamendi. Inventario de los animales vertebrados de la Reserva Natural Otamendi. Serie: Temas de Naturaleza y Conservación, Monografía 3. Buenos Aires: Aves Argentinas /Asociación Ornitológica del Plata. 191 pp.

Pereira, J., E. Haene \& M. Babarskas. 2003. Mamíferos de la Reserva Natural Otamendi. Pp. 115-139 in: Haene, E. \& J. Pereira (eds.). Fauna de Otamendi. Inventario de los animales vertebrados de la Reserva Natural Otamendi. Serie: Temas de Naturaleza y Conservación, Monografía 3. Buenos Aires: Aves Argentinas /Asociación Ornitológica del Plata. 191 pp.

Pereyra, J.A. 1938. Aves de la zona ribereña nordeste de la provincia de Buenos Aires. Memorias del Jardín Zoológico 9: 1-304.

Pereyra, J.A. 1965. Leucochloris albicollis en la provincia de Buenos Aires. Hornero 10(2): 279.

Povedano, H. \& F.N. Moschione. 1989. Nuevas aves para Punta Lara. II. Garganchillo 3(10): 16.

Ponce, M.M. 1987. Revisión de las Thelypteridaceae (Pteridophyta) argentinas. Darwiniana 28(1-4): 317-390.

Pugnali, G. \& P. Chamorro (compiladores). 2006. Lista de aves de la reserva ecológica Costanera Sur. Buenos Aires: Aves Argentinas /Asociación Ornitológica del Plata.

Ramos Giacosa, J.P., E.R. de la Sota \& G.E. Giudice. 2004. Actualización florística y análisis numérico de la biodiversidad de las Pteridofitas de la provincia de Buenos Aires. Boletín de la Sociedad Argentina de Botánica 39(1-2): 125-130.

Rapoport, E.H. 1996. The flora of Buenos Aires: low richness or mass extinction? International Journal of Ecology and Environmental Sciences 22: 217242.

Richard, E. \& M.S. de la Fuente. 1992. Lista sistemática y distribución de las tortugas argentinas (Reptilia: Chelonia). Acta Zoologica Lilloana 41: 357-364.

Ringuelet, R.A. 1955. Panorama zoogeográfico de la Provincia de Buenos Aires. Notas del Museo de La Plata, Zoología 18(156): 1-15.

Ringuelet, R.A. 1959. Los arácnidos argentinos del orden Opiliones. Revista del Museo Argentino de Ciencias Naturales Bernardino Rivadavia, Zoología 5(2): 128-439.

Ringuelet, R.A. 1961. Rasgos fundamentales de la zoogeografía de la Argentina. Physis 22(63): 151-170. 
Ringuelet, R.A. 1981. El ecotono faunístico SubtropicalPampásico y sus cambios históricos. Pp. 75-80 in: Symposia. VI Jornadas Argentinas de Zoología, La Plata, 18 al 23 de octubre de 1981.

Roesler, I. 2001. Nuevas citas de aves para el Partido de General Villegas, provincia de Buenos Aires, Argentina. Nuestras Aves 41:32-33.

Robertson, J.P. 1916. La Argentina en los primeros años de la revolución. Buenos Aires: Imprenta de la Nación. 237 pp.

Saibene, P., R. Cajade, L.G. Pagano \& R. Herrera. 2012. Reptiles de la Reserva Natural Punta Lara. Pp. 8396 in: Roesler, I. \& M.G. Agostini (eds.). Inventario de los vertebrados de la Reserva Natural Punta Lara, provincia de Buenos Aires, Argentina. Serie: Temas de Naturaleza y Conservación, Monografía 8. Buenos Aires: Aves Argentinas/Asociación Ornitológica del Plata. 200 pp.

Schnack, E.J. 2000. El Niño en el Plata. Museo, Revista Museo de La Plata 3(14): 71-76.

Sclater, P. 1890. Catalogue of the birds in the British Museum. Volume 15. London: British Museum. 316 $\mathrm{pp}$.

Sclater, P. \& W.H. Hudson. 1888. Argentine Ornithology. Vol. 1 \& 2. London: Porter.

Servicio Meteorológico Nacional. 2015. Cambio climático: Tendencias observadas en Argentina. Available in: www.smn.gov.ar/serviciosclimaticos $/$ $\bmod =c a$ mbioclim\&id $=7$.

Spegazzini, C.L. 1905. Flora de la provincia de Buenos Aires. Tomo I. Anales del Ministerio de Agricultura, sección de Biología Vegetal, Buenos Aires. 162 pp.

Spescha, L., A. Faggi \& O. Scarpati. 2004. La golondrina como indicador fenológico de cambio climático. Diversidad y Ambiente 1: Available in: http://institucional.uflo.edu.ar/uflo/institucional/files/varios/ volumen1/trabajo3/contenido.htm

Teta, P., A. Formoso, M. Tammone, D.C. de Tommaso, F.J. Fernández, J. Torres \& U.F.J. Pardiñas. 2014. Micromamíferos, cambio climático e impacto antrópico: ¿Cuánto han cambiado las comunidades del sur de América del Sur en los últimos 500 años? Therya 5: 7-38.

Teta, P., C.M. González-Fischer, M. Codesido \& D.N. Bilenca. 2010. A contribution from Barn Owl pellets analysis to known micromammalian distributions in Buenos Aires province, Argentina. Mammalia 74: 97-103.

Udrizar Sauthier, D.E., A.M. Abba, L.G. Pagano \& U.F.J. Pardiñas. 2005. Ingreso de mamíferos brasílicos en la provincia de Buenos Aires, Argentina. Mastozoología Neotropical 12(1): 91-95.

Vervoorst, F.B. 1967. La vegetación de la República Argentina. VII. Las comunidades vegetales de la depresión del salado (provincia de Buenos Aires). Buenos Aires: INTA, Instituto de Botánica Agrícola, serie Fitogeográfica. 259 pp.

Voglino, D., U.F.J. Pardiñas \& P. Teta. 2004. Holochilus chacarius chacarius (Rodentia, Cricetidae) en la provincia de Buenos Aires, Argentina. Mastozoología Neotropical 11: 243-247.

Walther, G.R. 2010. Community and ecosystem responses to climatic change. Philosophical Transactions of the Royal Society of London, B: Biological Sciences 365: 2019-2024.

Walther, G.R., E. Post, P. Convey, A. Menzel, C. Parmesan, T. Beebee, J. Fromentin, O. HoeghGuldberg \& F. Bairlein. 2002. Ecological responses to recent climate change. Nature 416: 389-395.

Wege, D.C. \& A.J. Long. 1995. Key areas for threatened birds in the Neotropics. BirdLife International Conservation Series 5. Cambridge (UK). 312 pp.

Williams, J.D. 1991. Anfibios y reptiles. In: Goin, F. \& R. Goñi (eds.). Situación ambiental de la provincia de Buenos Aires. Recursos y rasgos naturales en la evaluación ambiental. Vol. 1(5). La Plata: Comisión de Investigaciones Científicas de la Provincia de Buenos Aires.

Willmott, K.R. 2003. The genus Adelpha: Its systematics, biology and biogeography (Lepidoptera: Nymphalidae: Limenitidini). Gainesville, Florida: Scientific Publishers. 322 pp.

Withington, F. 1888. On the birds of Lomas de Zamora, Buenos Aires, Argentine Republic. With notes on P. L. Sclater. Ibis 1888: 461-473.

Zamorano, M. \& G.J. Scillato-Yané. 2008. Registro de Dasypus (Dasypus) novemcinctus (Mammalia, Dasypodidae) en el sudoeste de la provincia de Buenos Aires, Argentina. BioScriba 1(1): 17-26.

Zapata, L.V. \& C.J. Grismado. 2015. Las arañas (Arachnida: Araneae) de la Reserva Ecológica Costanera Sur, Ciudad Autónoma de Buenos Aires, Argentina. Revista del Museo Argentino de Ciencias Naturales "Bernardino Rivadavia", n.s. 17(2): 183-211.

Zelaya, D.G. \& J.H. Pérez. 1998. Observando aves en los bosques y lagos de Palermo, Ciudad de Buenos Aires. Buenos Aires: Athene. 26 pp.

Zotta, A.R. \& S. Da Fonseca. 1936. Sinopsis de los Ciconiformes Argentinos. Hornero 6: 240-248.

Zuloaga, F., O. Morrone \& M. Belgrano (eds.). 2008. Catálogo de las plantas vasculares del Cono Sur (Argentina, sur de Brasil, Chile, Paraguay y Uruguay), Volumes 1-3. Monographs in Systematic Botany from the Missouri Botanical Garden 107. 3348 pp. 